\title{
Australia: 2008 Article IV Consultation-Staff Report; Staff Supplement; Public Information Notice on the Executive Board Discussion; and Statement by the Executive Director for Australia
}

Under Article IV of the IMF's Articles of Agreement, the IMF holds bilateral discussions with members, usually every year. In the context of the Article IV consultation with Australia, the following documents have been released and are included in this package:

- $\quad$ The staff report for the 2008 Article IV consultation, prepared by a staff team of the IMF, following discussions that ended on July 1, 2008, with the officials of Australia on economic developments and policies. Based on information available at the time of these discussions, the staff report was completed on August 8, 2008. The views expressed in the staff report are those of the staff team and do not necessarily reflect the views of the Executive Board of the IMF.

- A staff supplement of September 5, 2008 updating information on recent developments.

- $\quad$ A Public Information Notice (PIN) summarizing the views of the Executive Board as expressed during its September 10, 2008 discussion of the staff report that concluded the Article IV consultation.

- $\quad$ A statement by the Executive Director for Australia.

The document listed below has been or will be separately released.

Selected Issues

The policy of publication of staff reports and other documents allows for the deletion of market-sensitive information.

\author{
Copies of this report are available to the public from \\ International Monetary Fund $\bullet$ Publication Services \\ $70019^{\text {th }}$ Street, N.W. $\bullet$ Washington, D.C. 20431 \\ Telephone: (202) 623-7430 • Telefax: (202) 623-7201 \\ E-mail: publications@imf.org Internet: http://www.imf.org
}

Price: $\$ 18.00$ a copy

\section{International Monetary Fund Washington, D.C.}



INTERNATIONAL MONETARY FUND

\begin{abstract}
AUSTRALIA
Staff Report for the 2008 Article IV Consultation

Prepared by the Staff Representatives for the 2008 Consultation with Australia Approved by Steven Dunaway and Tessa van der Willigen
\end{abstract}

August 8, 2008

- Discussions: Canberra, Melbourne, and Sydney, June 23-July 1, 2008, with Treasurer Wayne Swan, RBA Governor Glenn Stevens, Treasury Secretary Ken Henry, other senior officials, and representatives from labor unions, financial, and business sectors.

- Team: Messrs. Brooks (Head), Hunt, Rozhkov and Ms. Edison (all APD). Mr. Murray (OED) participated in the discussions.

- Focus of Mission: The mission focused on the policies needed to reduce inflation associated with the commodity boom and to maintain financial stability in the face of the global financial market turmoil.

- Past Surveillance: For policy issues discussed in the 2007 Article IV consultation, see: http://www.imf.org/external/np/sec/pn/2007/pn07112.htm.

- Political Context: The new Labor Government was elected to office in November 2007 and presented its first budget in May 2008.

- Exchange Rate: Market determined. Australia maintains an exchange system that is free of restrictions on the making of payments and transfers for current international transactions other than restrictions notified to the Fund in accordance with Decision No. 144-(52/51).

- Official Development Assistance: 0.3 percent of national income in 2008. 
Executive Summary.

Contents

I. The Economic Expansion and Commodity Price Boom ............................................4

II. How to Reduce Inflation and Sustain Economic Performance? ....................................11

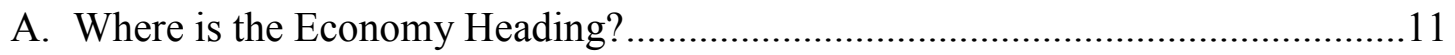

B. Appropriate Macroeconomic Policy Settings ........................................................ 13

C. Dealing with the Global Financial Market Turmoil ............................................19

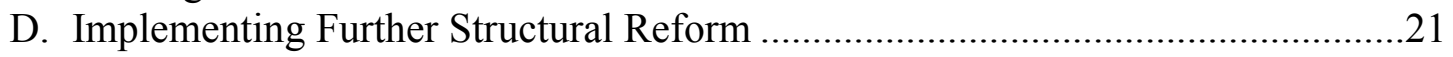

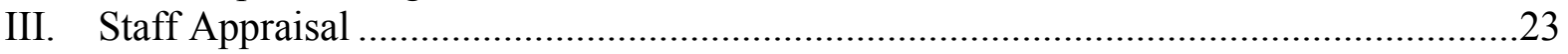

Tables

1. Selected Economic Indicators, 2004-09 …............................................................25

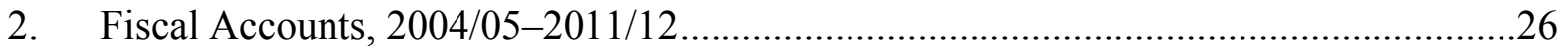

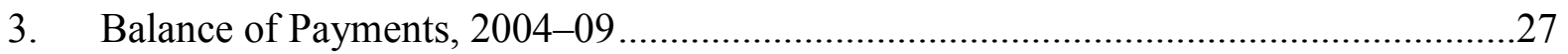

4. Balance of Payments in U.S. Dollars 2004-07 .......................................................28

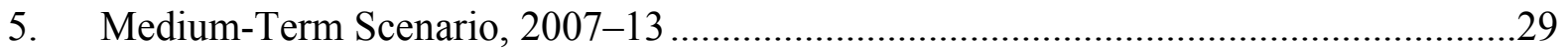

6. Indicators of External and Financial Vulnerability, 2004-08 ….................................30

7. Financial Sector Assessment Program ............................................................... 31

Figures

1. Prolonged Expansion and Commodity Boom Leads to Overheating ............................4

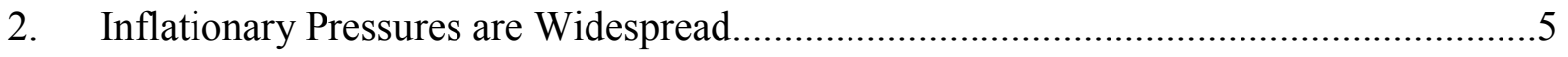

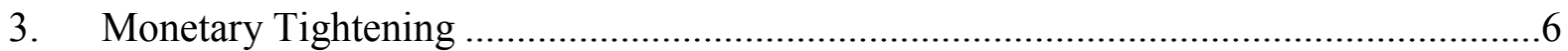

4. Fiscal Strength and the Commodity Boom ............................................................ 7

5. Current Account, Commodity Boom, and the Exchange Rate .....................................

6. The Continued Strength of the Banking Sector .....................................................

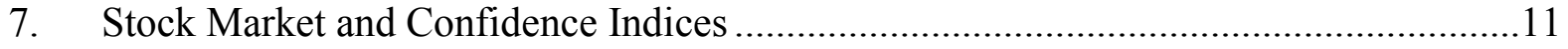

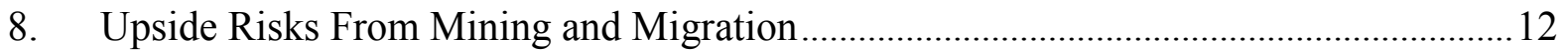

9. Expected Interest Differential and the Exchange Rate .......................................... 15

10. Foreign Debt, March 2008 ....................................................................................... 15

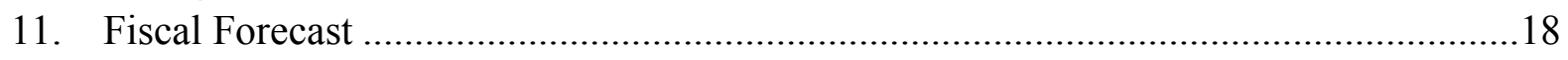

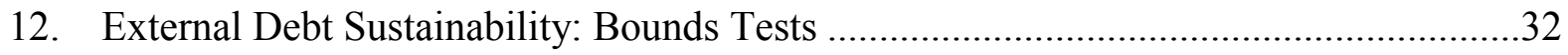

Boxes

1. Australian Banks and the Global Financial Turmoil: The Rollover Risk.......................10

2. The Potential Impact on Australia of a U.S. Slowdown ................................................ 14

3. Australia's Equilibrium Real Effective Exchange Rate............................................16

4. Structural Reform Agenda ............................................................................22

Appendix

I. Exchange Rate Assessment Methodology and Confidence Intervals ............................33 


\section{Executive Summary}

Sound macroeconomic policies and structural reforms have delivered a prolonged expansion, but the economy's productive capacity has become increasingly stretched. A commodity driven boom has pushed up against capacity constraints and inflation has increased especially over the past year as resource pressures mounted. The authorities and staff agreed that real GDP growth is likely to slow as required to ease inflation, and that the outlook is more uncertain than usual. In the staff's view, the balance of risk to growth lies on the upside, stemming from an extraordinary jump in commodity export prices. On inflation, the risks are clearly on the upside, reflecting capacity constraints, especially in the mining and housing sectors.

With underlying inflation the highest in more than a decade, containing inflation presents a significant challenge. A firm monetary policy stance is essential for keeping medium-term inflation expectations well anchored. Given that the risks to inflation are on the upside, the authorities and staff agreed that monetary policy should be tightened quickly if leading indicators suggest that domestic demand will not slow as expected or the outlook for inflation deteriorates.

Higher commodity export prices and capital inflows have contributed to the appreciation of the currency, which in turn has eased inflation pressures. As of June 2008, the staff estimated the real effective exchange rate (REER) to be about 10 percent above its long-run equilibrium level. The authorities and staff agreed that the overvaluation is temporary and that the currency is likely to fall back toward equilibrium over time as the Reserve Bank of Australia reduces the cash rate once it is clear that inflation will moderate. However, with a portion of the improvement in the terms of trade likely to be permanent, the currency is expected to remain above its average for the last 10 years.

The new Labor Government stressed that the priority for this year's budget is to help fight inflation by constraining spending and increasing the surplus. Saving some of the revenue from the commodity price boom in three new funds will take pressure off monetary policy in the near term and enable increased infrastructure investment over the medium term. The authorities agreed with the staff that if inflation persists at an elevated level, further fiscal restraint may be needed.

Australia's banks have demonstrated their soundness during the recent global financial turmoil, but some vulnerabilities remain. The main impact of the crisis was a sharp increase in funding costs, as banks had a small exposure to sub-prime assets. Although the major banks were able to maintain access to funding from offshore markets, the turmoil highlighted their vulnerability to rollover risks arising from short-term wholesale funding. In response, banks are increasing their liquidity as well as lengthening the maturity of their funding and diversifying the sources. The authorities are also taking measures to address rollover risk by introducing new liquidity guidelines. 


\section{The EConomic EXPAnsion ANd Commodity Price BoOM}

\section{Sound macroeconomic policies and structural reforms in Australia have} delivered more than 16 years of economic expansion, but the economy's productive capacity has become increasingly stretched. The pace of real GDP growth picked up in 2007 to more than 4 percent, driven by a commodity price boom in response to robust global demand for iron ore and coal, especially from China. The commodity price boom has elevated the terms of trade to its highest level since the Korean War and has boosted profits, employment, and wages, which has helped cushion the impact of a severe drought and the global financial market turmoil. However, the boom has pushed up against capacity constraints, with unemployment falling to the lowest rate since the mid-1970s and capacity utilization rising to historic highs in early 2008 (Table 1, Figure 1).

Figure 1. Australia: Prolonged Expansion and Commodity Boom Leads to Overheating

Australia has experienced more than 16 years of growth..

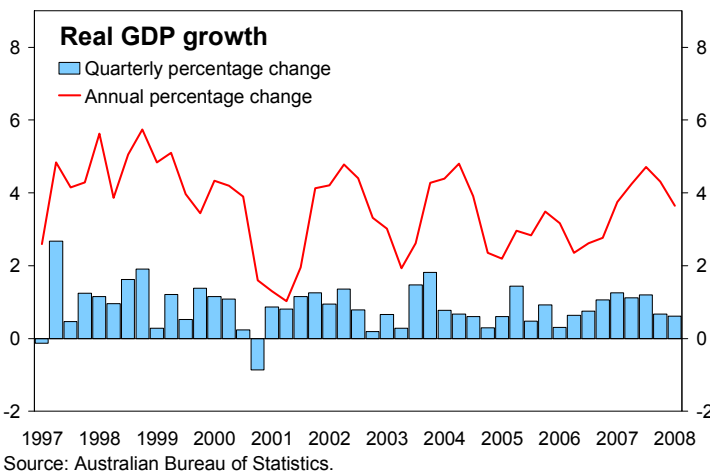

Domestic demand has been strong, led by a pickup in consumption in recent years.

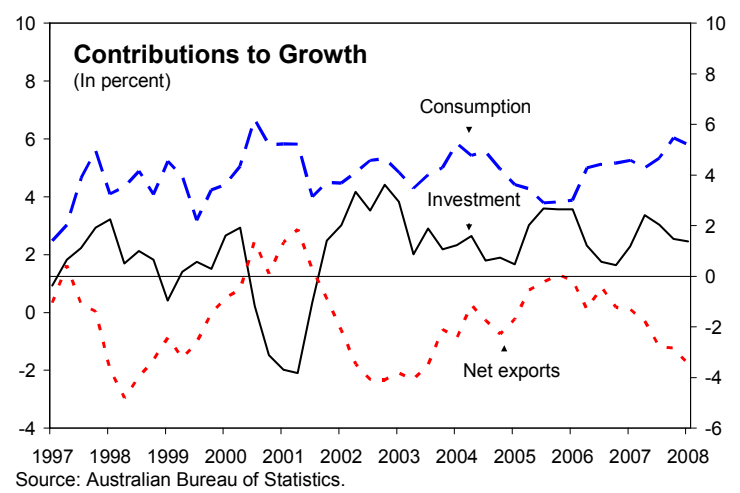

The commodity boom has been a major source of stimulus in recent years.

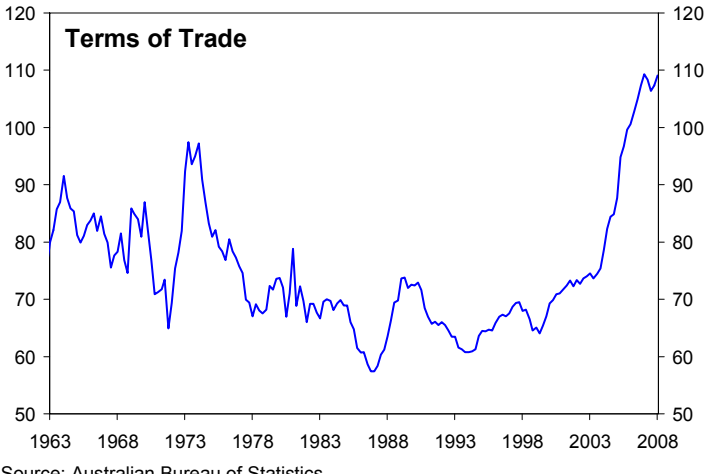
Source: Australian Bureau of Statistics.

As a result, capacity has been stretched.

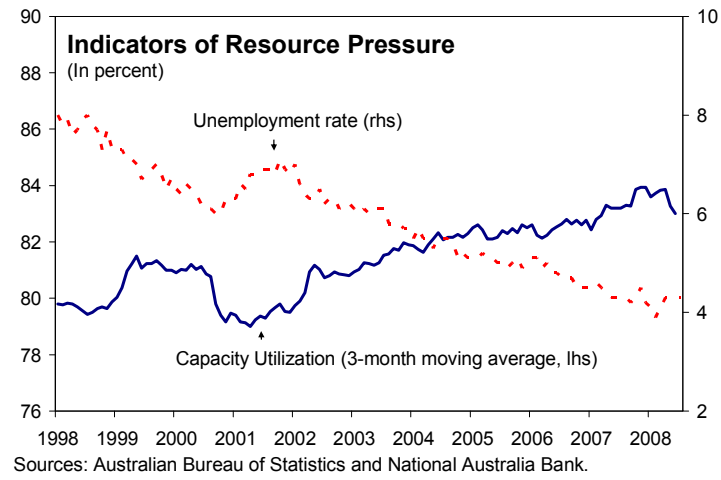


2. Inflation increased over the past year as resource pressures mounted. The

Reserve Bank of Australia's (RBA) measures of underlying inflation had been running close to the top of its target of "2-3 percent, on average, over the economic cycle" for some years, but rose to almost $4 \frac{1}{2}$ percent year on year in June 2008, the highest level in 16 years (Figure 2). The inflation pressures are broad-based, reflecting an increase in tradables inflation and wage growth.

Figure 2. Australia: Inflationary Pressures are Widespread

Nontradables inflation has been strong for some time, but both tradables and nontradables inflation rose in the past year...

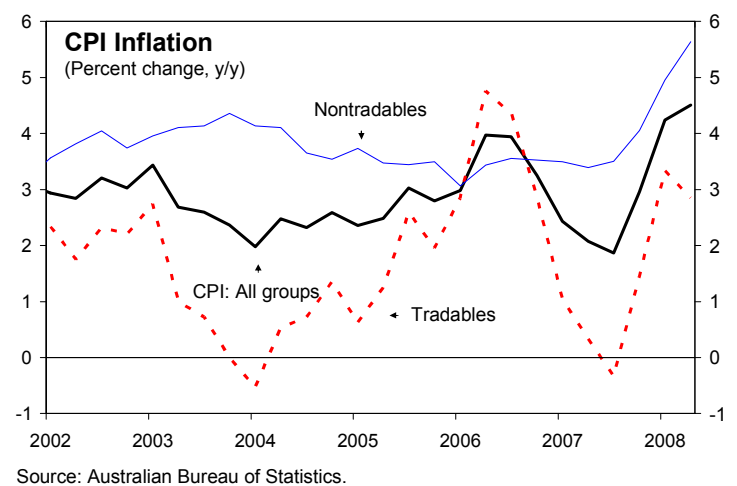

Inflation expectations have risen..

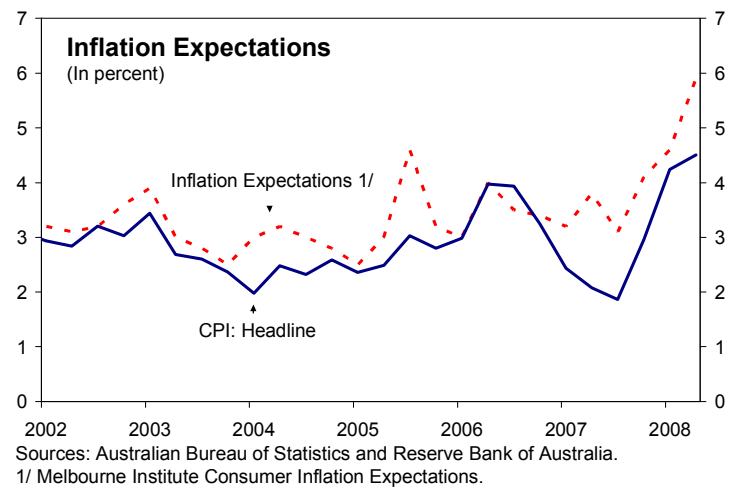

...contributing to higher core inflation.

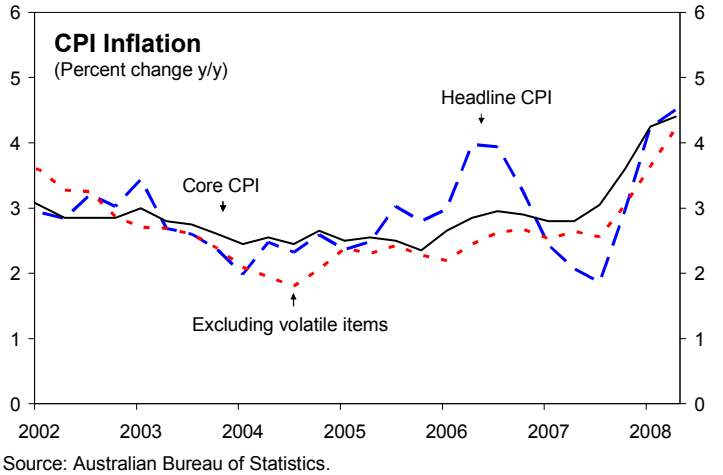

...and private-sector wage growth has trended up, as wages in the mining sector have increased strongly.

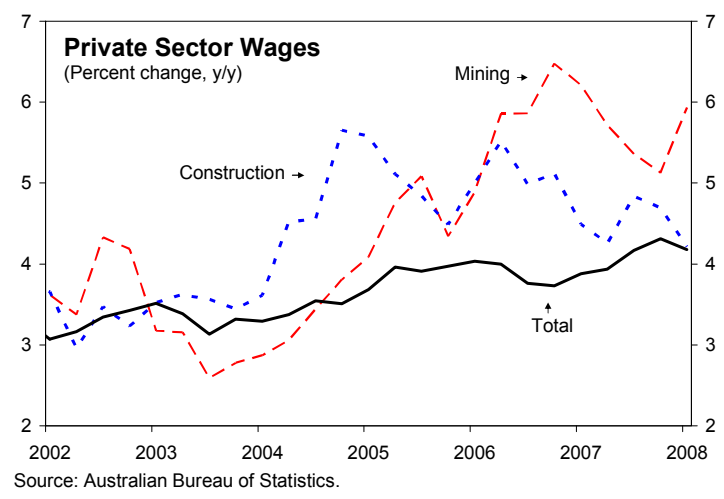

3. The RBA responded to the rising inflation by tightening monetary policy. Since 2002, the gradual increase in the policy rate has been passed through into retail rates, but the strength in the economy continued to surprise on the upside through end 2007 (Figure 3). Despite the onset of financial market turbulence last year, which prompted policy easing in many industrial countries, the underlying strength in the economy necessitated a renewed RBA tightening cycle. Between August 2007 and March 2008, the policy rate was increased by 100 basis points to $7 \frac{1}{4}$ percent. In addition, higher funding costs from the global financial 
turmoil have pushed up lending rates by a weighted average of around 60 basis points more than the rise in the policy rate over the period August 2007-July 2008. Inflation expectations have risen with the jump in food and energy prices, which has muted the impact of the recent increase in the policy rate, with real interest rates now around the average for the past five years. Nonetheless, credit growth has slowed sharply in recent months as tighter credit standards have been applied by financial institutions.

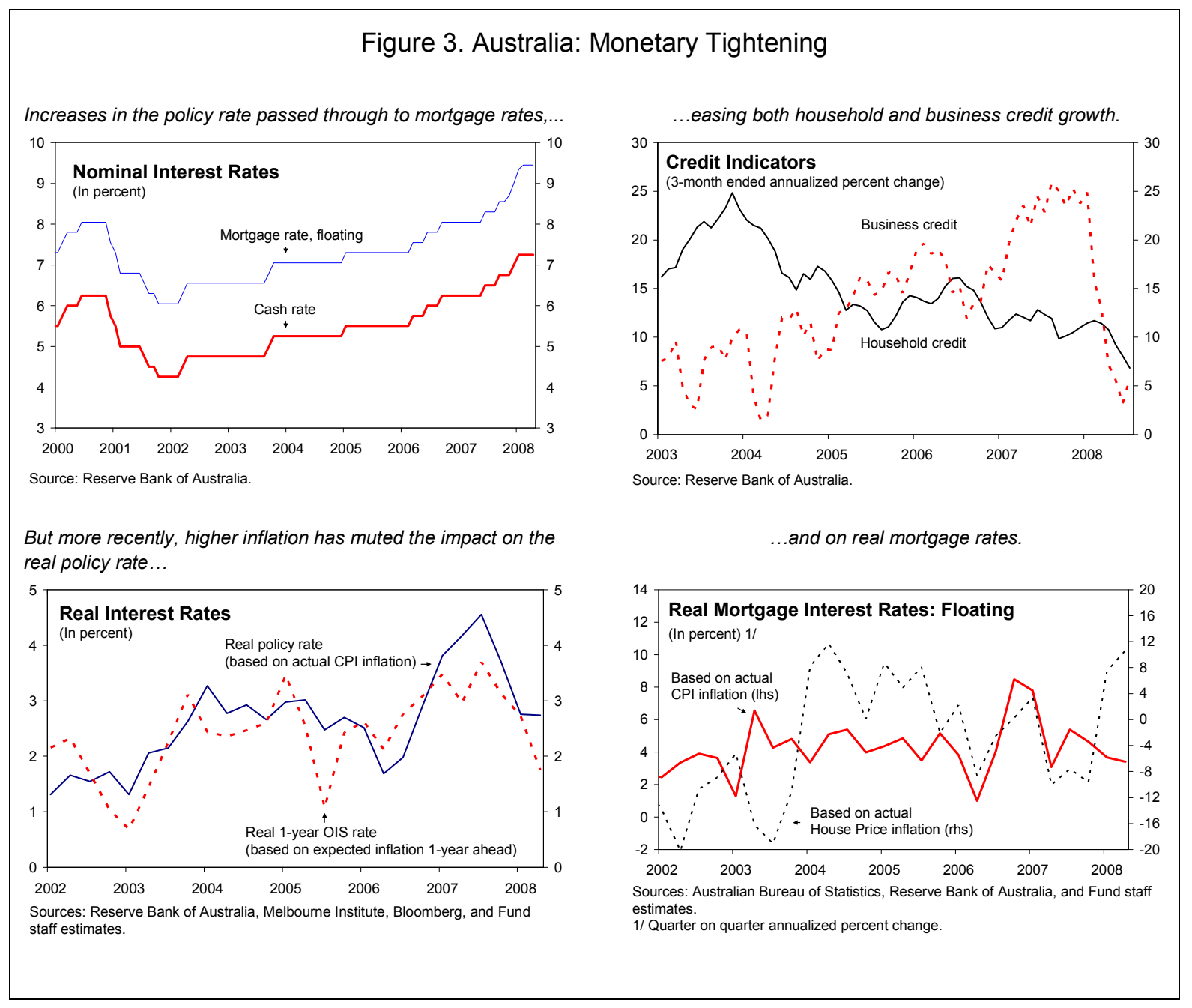

4. The Commonwealth's fiscal position has strengthened, but the states have begun

to run deficits. The Commonwealth government has run surpluses of around $1 \frac{1}{2}$ percent of GDP in recent years, which has eliminated its net debt (Figure 4, Table 2). Revenue outcomes have consistently surprised on the upside, driven by the stronger-than-expected economy and buoyancy in corporate tax revenue related to the commodity boom. However, increased spending and tax cuts over the last three years have offset some of the restraint from the automatic stabilizers. In addition, the states have increased capital spending and their budget balance has shifted to a deficit of about 1/2 percent of GDP in 2007/08. 


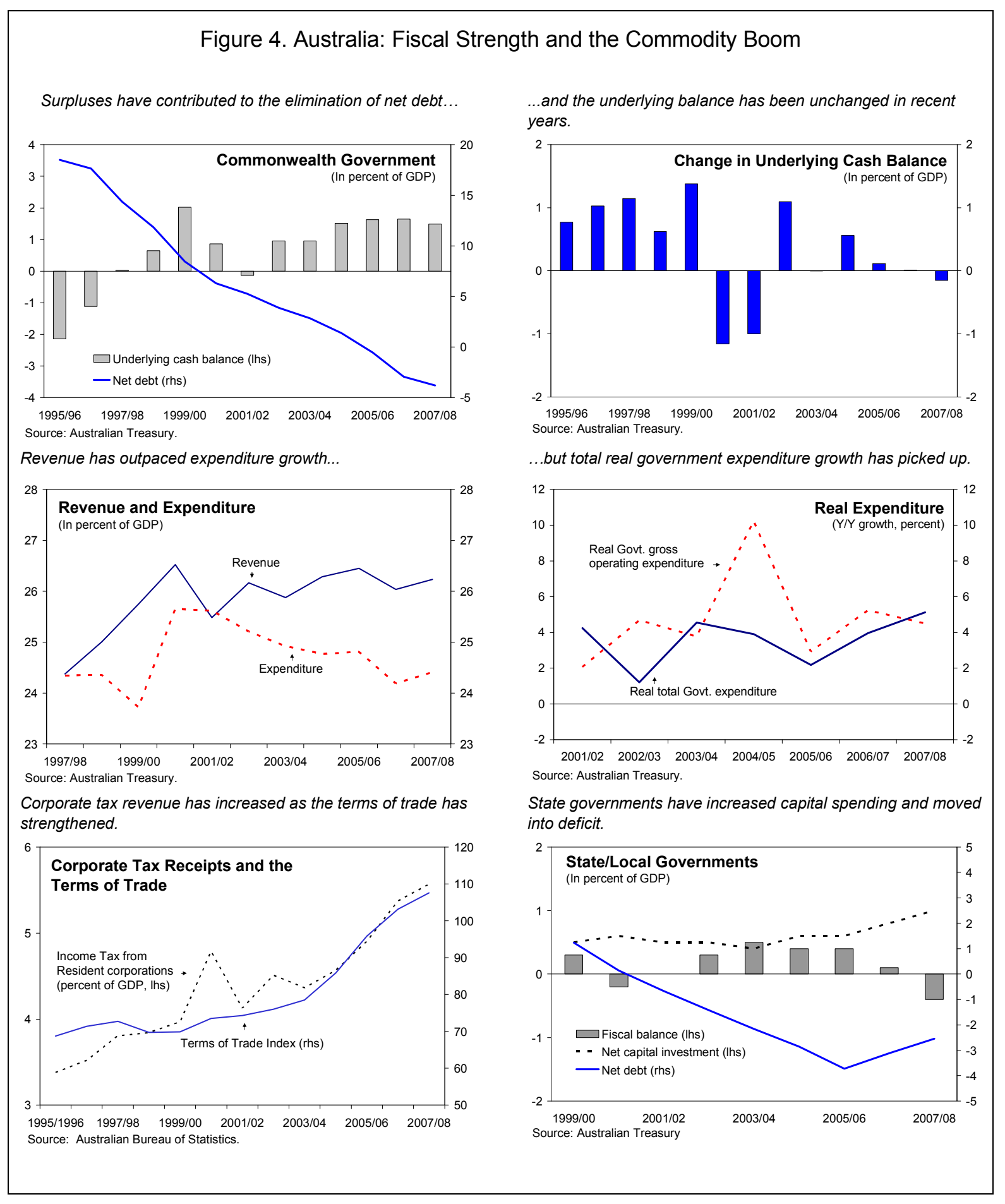

\section{The current account deficit widened in $\mathbf{2 0 0 7}$ to more than $\mathbf{6}$ percent of GDP,} despite the commodity boom (Figure 5, Tables 3 and 4). The trade deficit deteriorated, as export volume growth was constrained by drought disrupting rural exports and bottlenecks in the export supply chain. Imports also grew strongly owing to buoyant domestic demand and an appreciation of the real effective exchange rate (REER). In addition, the investment 
income deficit increased, reflecting higher interest payments on foreign debt and large dividend payments, particularly from the resource sector. Net foreign liabilities rose to 67 percent of GDP at end-March 2008, mainly owing to an increase in foreign debt, channeled primarily through financial institutions.

Figure 5. Australia: Current Account, Commodity Boom, and the Exchange Rate

The current account deficit widened due to higher interest and dividend payments.

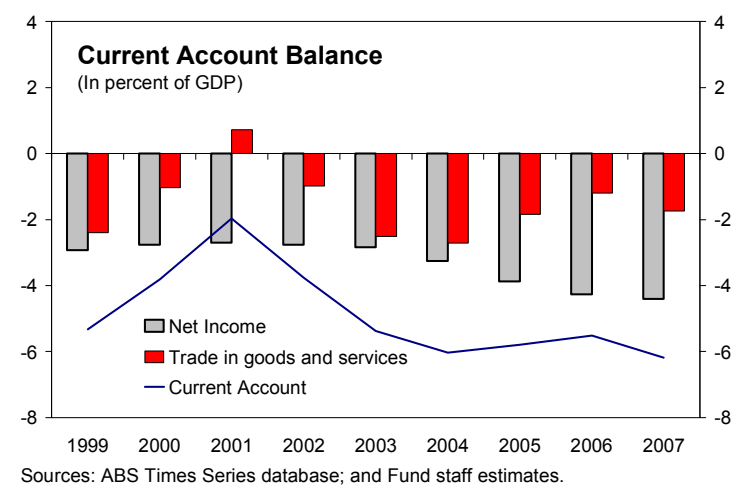

Capital inflows remain strong comprising mainly debt...

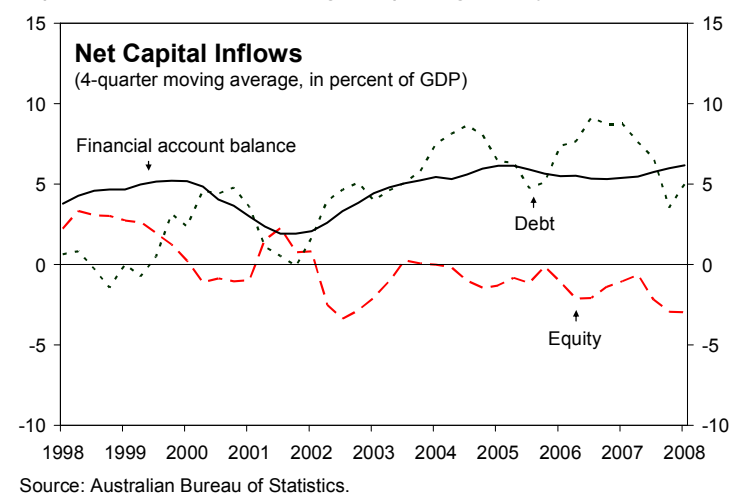

The real exchange rate has appreciated as commodity prices have risen sharply.

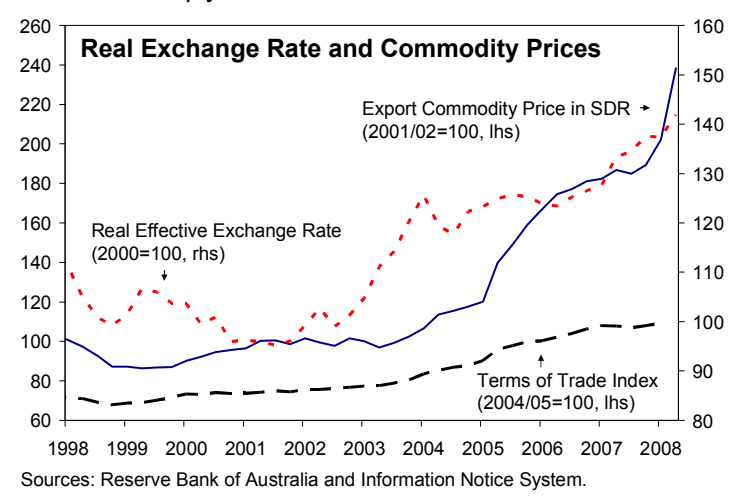

...contributing to a further increase in net foreign liabilities.

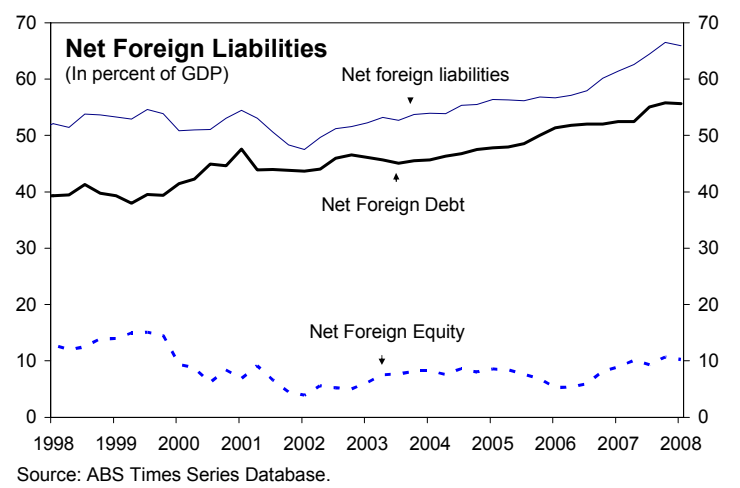

\section{Australian banks have weathered the global financial turmoil reasonably well.}

The four large banks that account for two-thirds of bank assets continued to report strong profits through early 2008, together with adequate capital. While impaired assets are very low ( 0.2 percent of assets), several large banks have increased their provisioning for bad debts to reflect the potential impact of a downturn and rising interest rates (Figure 6). The large banks have limited low-doc and nonconforming lending, with most of this activity concentrated in the smaller banks and the nonbank sector. ${ }^{1}$ The smaller banks have a higher

\footnotetext{
${ }^{1}$ Low-doc mortgages comprise 7 percent of total mortgages, and nonconforming (the equivalent of sub-prime) an additional 1 percent.
} 
impaired assets ratio (around $1 / 2$ of a percent) than the four large banks, but this ratio is low by international standards. Moreover, the smaller banks remain well capitalized, with the aggregate capital ratio in excess of 10 percent.

Figure 6. Australia: The Continued Strength of the Banking Sector

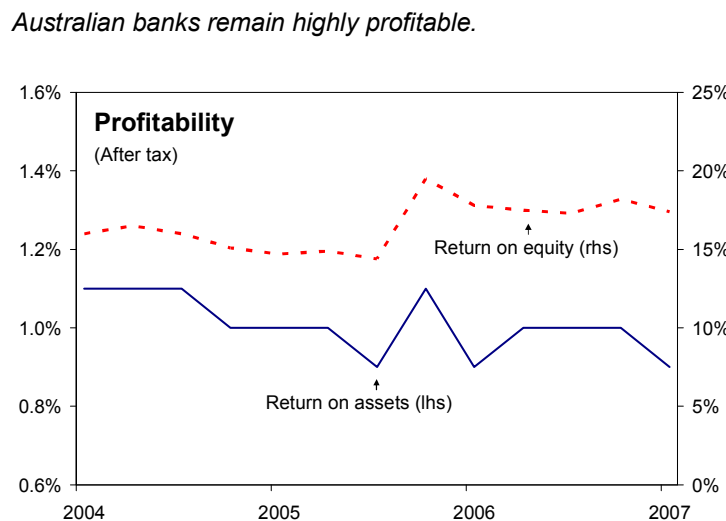

Source: Australia Prudential Regulation Authority.

....and impaired assets are very low by international standards and well covered by provisions.
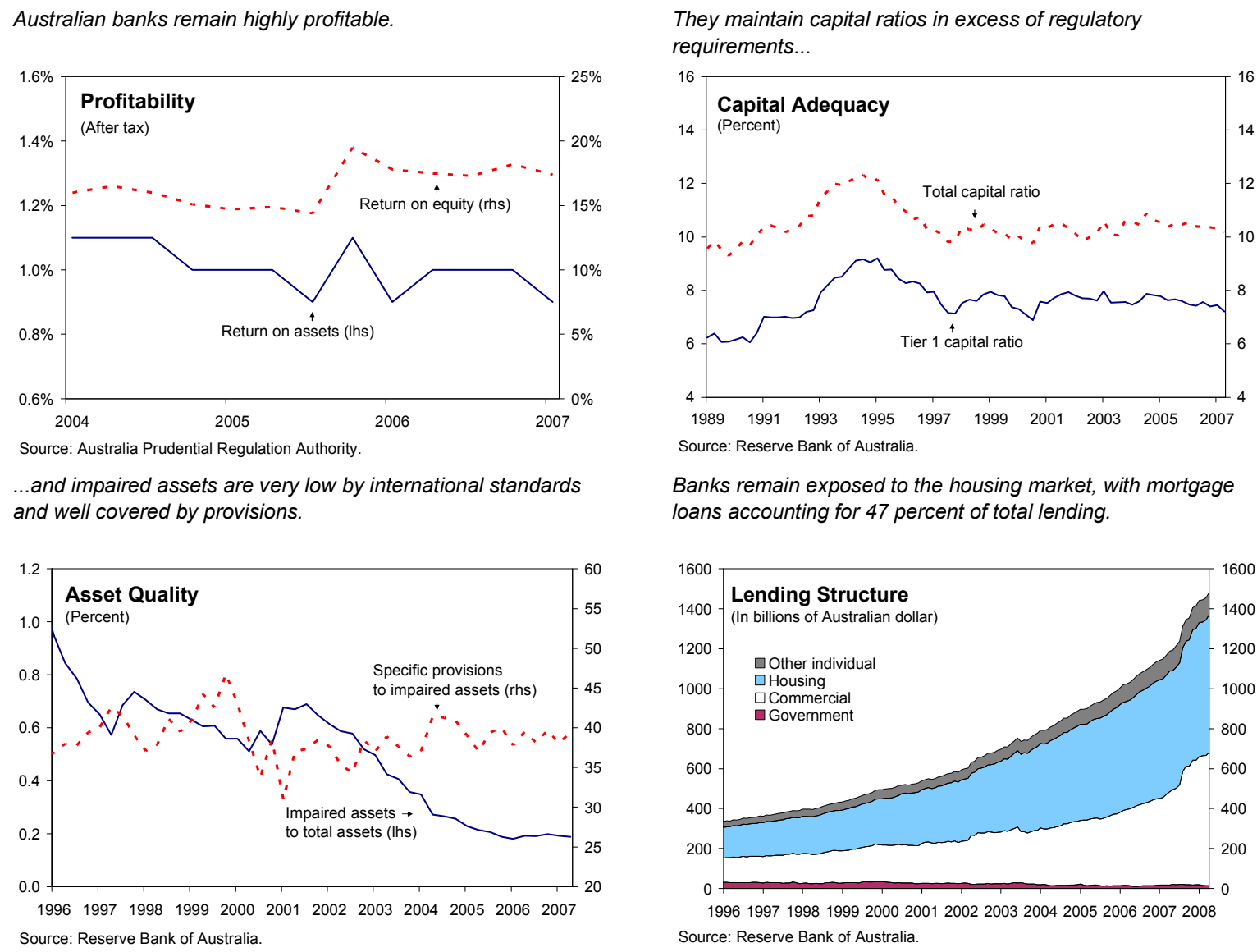

Banks remain exposed to the housing market, with mortgage loans accounting for 47 percent of total lending.

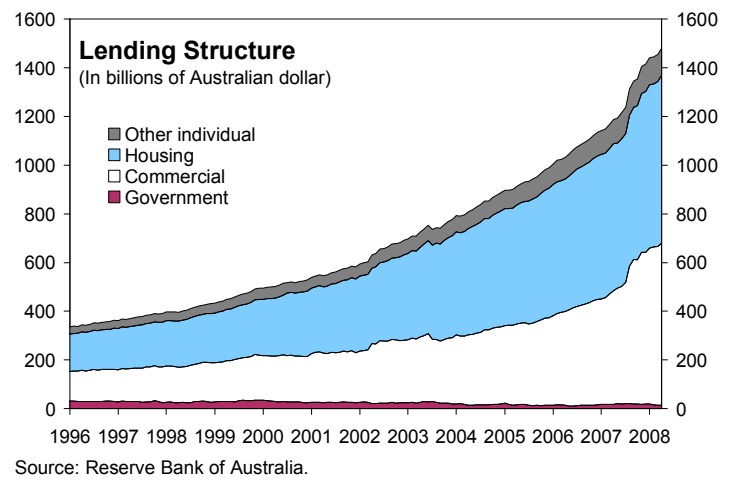

\section{The turmoil, however, highlighted the vulnerability of Australia's financial}

institutions to rollover risk. Sizable short-term funding from the wholesale market, including from offshore, has resulted in an increase in funding costs (Box 1). Some of the smaller financial institutions that relied more heavily on capital markets, particularly securitization, for funding were more affected by the higher cost of funding than institutions that had sizable deposit bases. As a consequence, the availability of home mortgages from these institutions has fallen, especially for low-doc and sub-prime borrowers, and large banks have increased their market share for prime mortgage lending. Corporates have issued fewer bonds because of the turmoil, and instead have approached the banks for funding. This 


\section{Box 1. Australian Banks and the Global Financial Turmoil: The Rollover Risk}

Australian banks are financially sound, but the global turmoil has highlighted their vulnerability to rollover risk associated with short-term wholesale funding. Wholesale funds account for about 60 percent of total funding of the banking system, and more than 40 percent of wholesale funds come from offshore. Furthermore, about 30 percent of offshore funds and 75 percent of domestic wholesale funds of Australian banks have residual maturity of less than one year. This funding structure makes the banks dependent on a stable international and domestic funding environment, and leaves them vulnerable to increases in the cost of funds and to the protracted loss of access to international shortterm debt markets.

\begin{tabular}{|lrrr|}
\hline \multicolumn{4}{c|}{$\begin{array}{c}\text { Australian Banks' Liabilities } \\
\text { (Percent of total) }\end{array}$} \\
\hline & Jun 07 & Dec 07 & May 08 \\
\hline Deposits (ex CDs) & 42.6 & 40.0 & 40.6 \\
Of which: Household & 17.2 & 16.3 & 16.6 \\
$\quad$ Business & 14.0 & 13.3 & 12.6 \\
$\quad$ Intra-group & 3.1 & 4.1 & 4.8 \\
Domestic wholesale & 30.7 & 34.6 & 34.0 \\
Offshore & 26.7 & 25.4 & 25.4 \\
Total liabilities & 100.0 & 100.0 & 100.0 \\
\hline Sources: APRA; RBA & & \\
\hline
\end{tabular}

The global turmoil resulted in a sharp increase in funding costs in both domestic and offshore debt markets. The spread between the 3-month bank bill rate and the overnight index swap (OIS) rate averaged around 50 basis points in March-July 2008, compared to the average of 10 basis points in recent years. Furthermore, credit default swap spreads for the major Australian banks widened sharply during the same period, also indicating a higher cost of funding.

Despite the turmoil, the large Australian banks have maintained access to wholesale markets to refinance themselves and to finance growth in their assets, albeit at significantly higher spreads. In addition, they have been attempting to improve their liquidity, by attracting more deposits and issuing short-term securities to one another (increasing the supply of eligible securities that can be used for repos with the RBA).

Banks are also attempting to change their funding structure, by issuing longer-term securities domestically and offshore, in particular through private placements of one-year extendible bonds in the United States and through issuance of yen-denominated "samurai" bonds for the first time. However, changing the maturity profile has been costly, as investors globally are demanding high premia for term funding. As a result, the share of offshore wholesale funding has fallen by only $1 \frac{1 / 4}{4}$ percentage point over the period June 2007-May 2008, to 251/2 percent of total liabilities, and the debt structure of Australian banks remains predominantly short term.
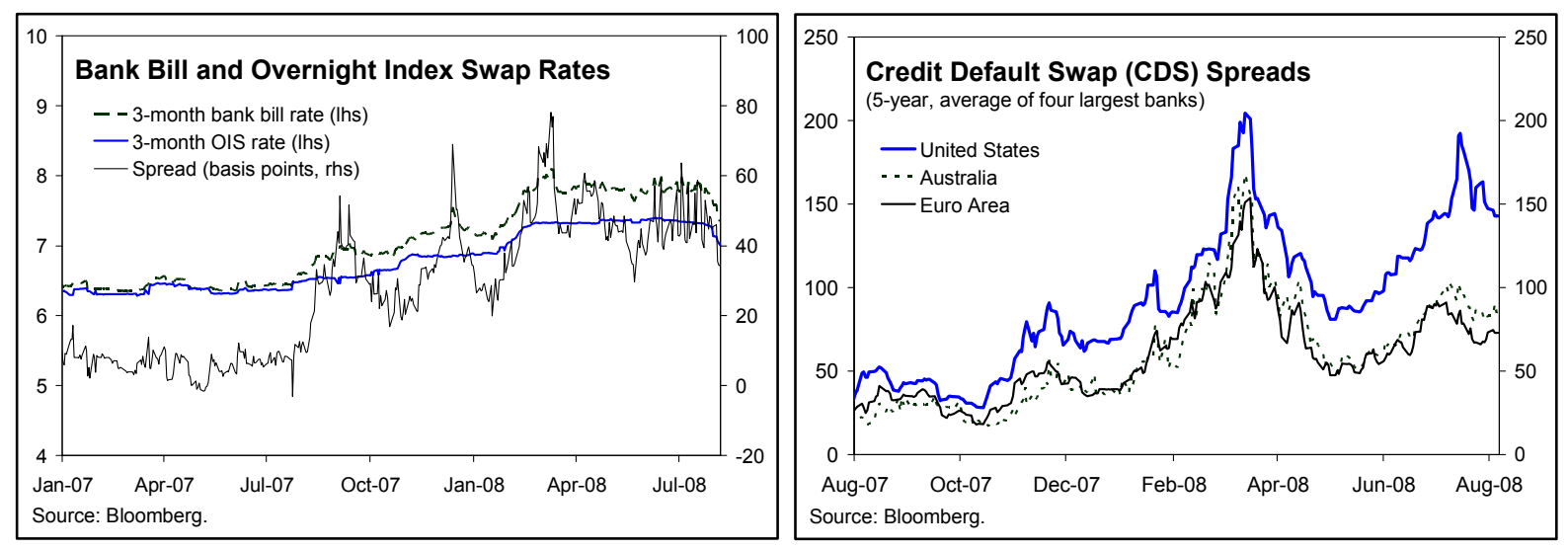
contributed to an increase in financial institutions' business credit growth in early 2008, but business credit growth has declined in recent months with the increase in interest rates and some tightening of credit standards.

\section{How to Reduce Inflation And Sustain Economic Performance?}

8. Discussion focused on the policies needed to reduce inflation associated with the commodity boom and to maintain financial stability in the face of the global financial market turmoil.

\section{A. Where is the Economy Heading?}

\section{Baseline. The staff and authorities agreed that activity is slowing, and that the} outlook is more uncertain than usual because of large countervailing forces. Growth in real domestic demand has begun to ease with the tightening of financial conditions, higher energy and food prices, and a sharp decline in confidence (Figure 7). However, the dampening effect of tighter credit conditions and slower trading partner growth is being cushioned by an 80-240 percent jump in annual contract prices for the key exports of iron ore and coal, that will increase the terms of trade by 20 percent in 2008/09, and cuts in personal income taxes. ${ }^{2}$ Staff's baseline forecast is that real GDP will grow below trend for the next two years, easing domestic capacity constraints and returning CPI inflation back within the target band over the period (Table 5). The current account deficit should narrow to $4 \frac{1}{4}$ percent of GDP in 2009

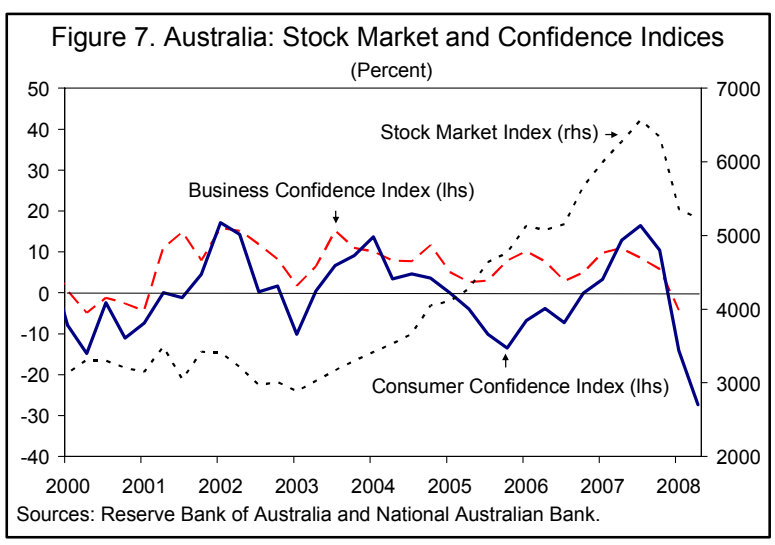
due to slower domestic demand growth, the jump in export prices, a rebound in rural exports, and mining sector capacity coming on line.

\section{The staff viewed the balance of risk to growth is tilted toward the upside and} that the risks on inflation were clearly on the upside.

- Upside Risks. Growth could exceed expectations, owing to the recent jump in commodity prices, sizable immigration flows, and the increase in state infrastructure spending (Figure 8). These factors could offset the impact of weaker consumer and business confidence and support domestic demand. On inflation, the risks are clearly on the upside. Capacity constraints, especially in the mining and housing sectors, could push wage and CPI inflation higher than envisaged.

\footnotetext{
${ }^{2}$ Cuts in personal income taxes that were introduced on July 1, 2008 will reduce revenue by about 2 percent of GDP over the next four years. Further cuts in personal income taxes to be phased in from 2009/10 to 2011/12 will reduce revenue by about 1 percent of GDP over that period.
} 
Figure 8. Australia: Upside Risks From Mining and Migration

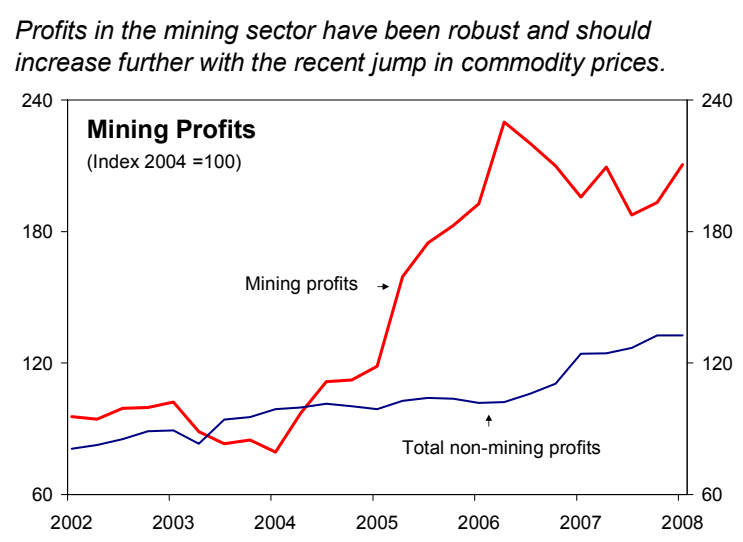

Source: Australian Bureau of Statistics.

Investment intentions have risen, especially in the mining sector.
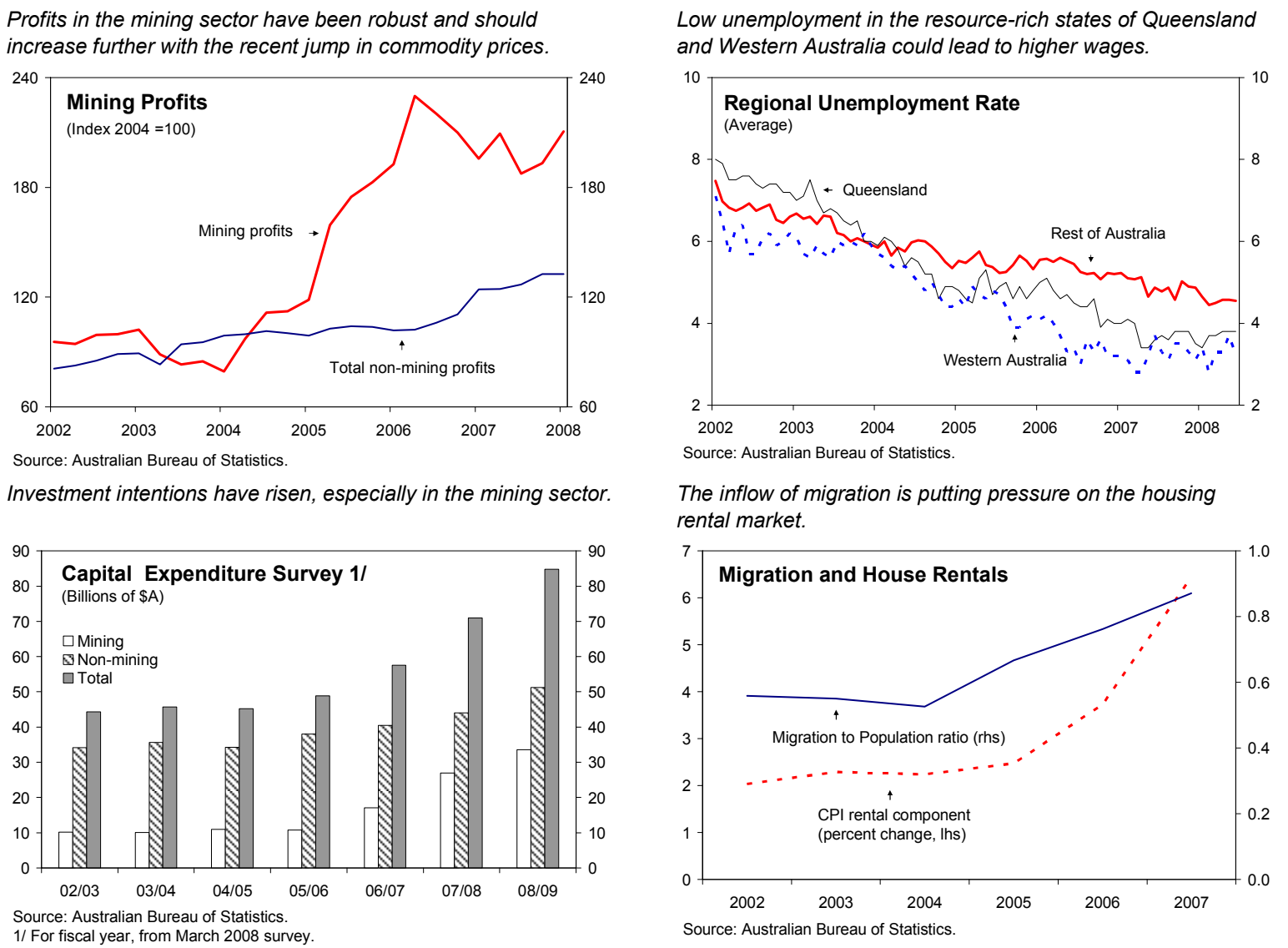

- Downside risks. On the domestic front, activity could slow significantly if the tightening in credit conditions apparent in the sharp fall in credit growth in recent months has a greater-than-expected impact on domestic demand. In addition, farm output may not rebound from the drought as projected. On the external front, a global slump could weaken export demand and reduce commodity prices, although the oneyear contracts for iron ore and coal would delay the impact on the economy. Further international financial turmoil could tighten credit conditions, leading to a sharperthan-expected slowing in global activity.

11. The authorities viewed risks to the outlook for growth to be more balanced than the staff. For growth, household spending may fall more than expected as consumer sentiment has declined sharply in face of higher fuel prices and mortgage rates. The authorities agreed that there is an upside risk to inflation, stemming from the extraordinary jump in the terms of trade. 


\section{B. Appropriate Macroeconomic Policy Settings}

\section{Monetary Policy}

12. The staff advised that a firm monetary policy stance is vital for keeping mediumterm inflation expectations well anchored. With underlying inflation the highest in more than a decade, containing inflation presents a challenge. The risk that wage inflation will rise further if CPI inflation persists at current levels calls for the RBA to maintain a tight policy stance until it is clear that inflation will abate. Reducing inflation back within the target range will require a significant easing in domestic demand growth. Further tightening may be necessary if the global financial market turmoil eases and business and consumer confidence rebounds. In particular, the slowdown in the United States may not be as severe as projected or the knock-on effects to the region may be limited (Box 2). With the risks to inflation on the upside, the RBA should be prepared to tighten quickly if leading indicators suggest that domestic demand will not slow as expected or the outlook for inflation deteriorates.

13. The authorities agreed that a firm monetary policy stance was necessary. They noted that the sequence of changes to the cash rate since August 2007, other adjustments by lenders in response to the rise in funding costs, and tighter credit standards have combined to produce financial conditions that were tight. The authorities considered that this tightening was already resulting in slower growth in domestic demand. Moreover, they believed that the tightening to date would be sufficient to reduce growth to below trend for the next two years thereby easing capacity pressures and reducing inflation to less than 3 percent by end- 2010 . They indicated that if the expected moderation in domestic demand does not occur or if expectations of high ongoing inflation begin to affect wage and price setting they would not hesitate to tighten policy further.

14. The authorities remain fully committed to the inflation-targeting framework, which has been subject to some public criticism in recent months. Several academics have argued that inflation targeting is not well suited to dealing with negative shocks such as the global increase in energy and food prices. The authorities have emphasized publicly that there is no reason to believe that this shock cannot be handled by sensible implementation of the RBA's inflation-targeting framework. The staff and authorities agreed that the benefits of the framework can be illustrated most clearly when there are large shocks to inflation. Despite the pickup in short-term inflation expectations, the absence to date of a notable acceleration in wage inflation demonstrates that the RBA's inflation target has helped to anchor medium-term inflation expectations.

\section{Recent steps to improve the transparency of monetary policy decision making} should enhance public understanding of monetary policy decisions. Since December 2007, the RBA has published a statement explaining the board's interest rate decision at the conclusion of every policy meeting, regardless of whether the cash rate is changed. This is followed two weeks later by the release of detailed meeting minutes. 


\section{Box 2. The Potential Impact on Australia of a U.S. Slowdown}

Two models have been used to estimate the potential impact of a U.S. slowdown: the IMF's Global Economy Model (GEM), calibrated to include Australia, and an estimated small model of Australia and the United States. The analysis is done in several steps. The first step looks at the trade impact alone coming from weaker U.S. import demand and the appreciation in the Australian dollar resulting from lower U.S. interest rates. The second step attempts to add the potential impact that could come through other channels such as financial market linkages and expectations. This is done by using the correlation between U.S. GDP and Australian GDP from the small model (see charts) to calibrate correlated shocks to private consumption and investment demand outside the United States. The third step holds the monetary policy rate in Australia unchanged for the first year.

The simulated impact of the trade effect alone is small (Scenario 1). In 2008, GDP and inflation in Australia fall by 0.2 percent, allowing a 50 basis point easing in the policy interest rate. The impact dissipates quickly with the economy back to baseline by 2010. The total potential impact based on the small model, however, is larger (Scenario 2), reflecting the historical correlation. If the policy rate in Australia is not changed in the first year in response to the slowdown, inflation falls by roughly 1.5 percentage points by the second year (Scenario 3). Given the current rate of CPI inflation in Australia, such a decline would return inflation to the top end of the RBA's 2-3 percent target.

Because the estimation period for the small model starts in the early $1990 \mathrm{~s}$, the correlation between Australian and U.S. GDP may be overstated. Over the period, Australia has become more integrated with emerging Asian countries. As a result, the total simulated effect should be thought of as an upper bound on what might occur.

The Impact on Australia of a U.S. Slowdown

(Percent or percentage point deviation from baseline)

\begin{tabular}{|c|c|c|c|c|c|c|c|c|c|c|c|c|}
\hline & \multicolumn{3}{|c|}{$\begin{array}{l}\text { United States } \\
\text { Slowdown }\end{array}$} & \multicolumn{3}{|c|}{$\begin{array}{c}\text { Australia: Scenario } 1 \\
\text { Trade Impact Only }\end{array}$} & \multicolumn{3}{|c|}{$\begin{array}{l}\text { Australia: Scenario } 2 \\
\text { Potential Total Impact }\end{array}$} & \multicolumn{3}{|c|}{$\begin{array}{l}\text { Australia: Scenario } 3 \\
\text { Total with Policy Rate } \\
\text { At Baseline First Year }\end{array}$} \\
\hline & 2008 & 2009 & 2010 & 2008 & 2009 & 2010 & 2008 & 2009 & 2010 & 2008 & 2009 & 2010 \\
\hline GDP (level) & -2.8 & -4.5 & -1.8 & -0.2 & 0 & 0 & -0.2 & -1.6 & -1.4 & -2 & -3.1 & -2.5 \\
\hline $\mathrm{CPI}$ inflation & -0.9 & -0.8 & -0.1 & -0.2 & -0.1 & 0 & -0.4 & -0.7 & -0.2 & -1.4 & -1.5 & -0.5 \\
\hline Policy rate & -2.4 & -2.3 & -0.9 & -0.5 & -0.3 & 0 & -1.5 & -2.2 & -1 & 0 & -1.6 & -1.3 \\
\hline
\end{tabular}




\section{Exchange Rate and External Stability}

16. The appreciation of the Australian dollar in recent years has been driven by the higher terms of trade and positive interest rate differentials. The stronger exchange rate has eased inflation pressures directly through lower import prices, and indirectly by switching expenditure to imports as domestic capacity became stretched. ${ }^{3}$ The staff estimate that the currency was about 10 percent above its long-run equilibrium level as of June 2008 (Box 3 and Figure 9). The staff and the authorities agreed that the overvaluation of the exchange rate is temporary, owing to cyclical reasons. Over time, the

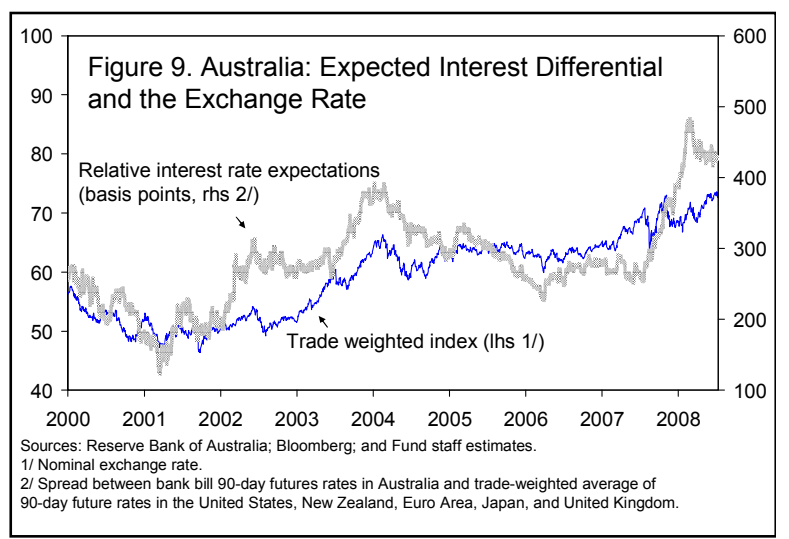
currency is expected to fall back toward equilibrium as the RBA reduces the cash rate once it is clear that inflation will moderate. However, with a portion of the improvement in the terms of trade likely to be permanent, the currency is expected to remain above its average for the last 10 years.

\section{The widening of the current account deficit in recent years and the buildup in} foreign debt has increased external vulnerability. The recent global financial turmoil highlighted the rollover risks associated with the sizable short-term foreign debt (Figure 10). Looking ahead, the current account deficit is projected to narrow in 2009 to about the estimated norm of $4-4 \frac{1}{2}$ percent of GDP and then widen somewhat over the medium-term as commodity prices ease from the peak in 2008/09. These projections are based on the assumption of a constant REER at June 2008 levels, and a depreciation of the

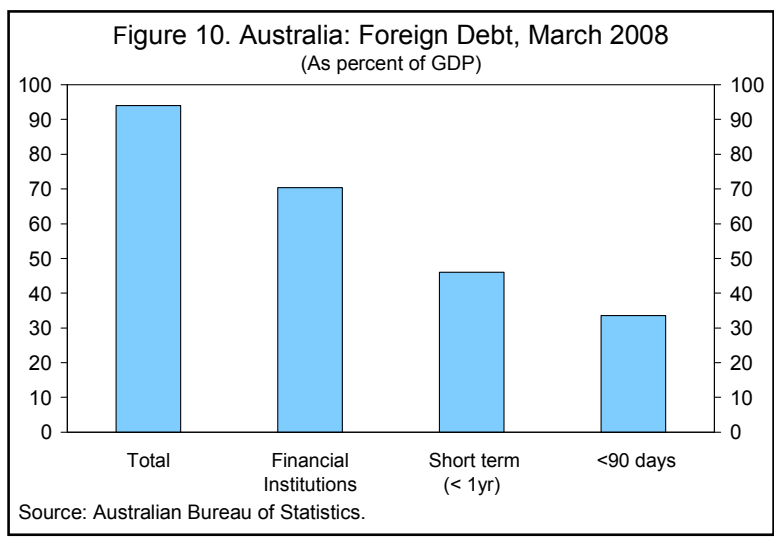
REER to equilibrium would narrow the current account further. In turn, this would slow the accumulation of external liabilities and help to contain vulnerability.

\footnotetext{
${ }^{3}$ The exchange rate is market-determined. In the past year, the RBA intervened to counter disorderly movements in the exchange rate and to maintain sufficient net official reserves. Net official reserves increased by $\$ A 4$ billion in the year to June 2008 and remained at about 13/4 months of imports. Gross official reserves fell by almost $\$$ A 40 billion over the year to June 2008 as forward contracts expired. These contracts were used for liquidity management.
} 


\section{Box 3. Australia's Equilibrium Real Effective Exchange Rate}

Staff estimates suggest that the Australian dollar was overvalued by about 10 percent as of June $2008 .{ }^{1}$ These estimates are based on the macroeconomic balance (MB) approach, the equilibrium real exchange rate (ERER) approach, and the external sustainability (ES) approach. The desk methodology is outlined in Appendix I.

The baseline MB estimates suggest an overvaluation of 7-9 percent over the medium term, while the overvaluation in 2008 is about $61 \frac{1}{2}$ percent. The estimates are subject to significant uncertainty, as shown by varying the projected underlying current account deficit and changing the elasticity of the current account balance with respect to the REER. Plausible sensitivity analysis suggests that the overvaluation is about $2-22$ percent.

The baseline ERER estimates suggest an overvaluation of 7-12 percent. The models attempt to explain the REER on the basis of the terms of trade, relative productivity, and relative government consumption. An important determinant is the terms of trade, with the 42 percent improvement over the past five years contributing to an increase in the equilibrium REER of about 15 percent. The overvaluation in 2008 is estimated at 10 percent, which narrows slightly to 7 percent by 2013 as the terms of trade is expected to rise.

\section{The ES approach implies an} overvaluation of 11 percent, if we assume that net foreign liabilities stabilize at their March 2008 level of 67 percent of GDP. A larger overvaluation would result if we assume that net foreign liabilities stabilize at their average level for the past 10 years of 55 percent of GDP.

\footnotetext{
${ }^{1}$ The corresponding equilibrium value of the RBA's real trade weighted index (TWI) is 128-135, assessed relative to an estimate for June 2008 of 145. This estimate is based on real TWI data for March 2008 updated with TWI data through June 2008. The nominal TWI index was at 73.4 as of end-June.
}

\begin{tabular}{|c|c|c|c|}
\hline \multicolumn{4}{|c|}{ Exchange Rate Assessment: Baseline Results ${ }^{1}$} \\
\hline & \multicolumn{2}{|c|}{ CA/GDP } & \multirow{2}{*}{$\begin{array}{c}\text { REER } \\
\text { Overvaluation }\end{array}$} \\
\hline & Norm & Projection $^{2}$ & \\
\hline \multicolumn{4}{|c|}{ MB Approach: ${ }^{3}$} \\
\hline Desk & -4.3 & -5.6 & 8.6 \\
\hline CGER & -4.5 & -5.6 & 6.9 \\
\hline \multicolumn{4}{|c|}{ ERER Approach: ${ }^{4}$} \\
\hline Desk & $\ldots$ & $\ldots$ & 6.9 \\
\hline CGER & $\ldots$ & $\ldots$ & 11.9 \\
\hline \multicolumn{4}{|c|}{ ES Approach: ${ }^{5}$} \\
\hline Desk & -4.0 & -5.6 & 10.7 \\
\hline \multicolumn{4}{|c|}{$\begin{array}{l}\text { Source: Fund staff estimates. } \\
\text { 1/ All results are expressed in percent and CGER estimates based on April } 2008 \text {. } \\
\text { 2/ Staff projection of the underlying CA/GDP in } 2013 \text {. } \\
\text { 3/ Based on a semi-elasticity of the CA/GDP with respect to the REER of }-0.16 \text {. } \\
\text { 4/ Overvaluation is assessed relative to June } 2008 \text {. } \\
\text { 5/ Based nominal GDP growth rate of } 6.4 \text { percent. }\end{array}$} \\
\hline \multicolumn{4}{|c|}{ MB Approach: Sensitivity Analysis ${ }^{1}$} \\
\hline & \multicolumn{3}{|c|}{ CA/GDP Projection ${ }^{2}$} \\
\hline Elasticity & -4.6 & -5.6 & -6.6 \\
\hline-0.11 & 3.2 & 12.8 & 22.3 \\
\hline-0.16 & 2.2 & 8.6 & 15.1 \\
\hline-0.21 & 1.7 & 6.5 & 11.4 \\
\hline \multicolumn{4}{|c|}{$\begin{array}{l}\text { Source: Fund staff estimates. } \\
\text { 1/ REER overvaluation is expressed in percent. } \\
\text { 2/ Staff projection of the underlying CA/GDP in } 2013 .\end{array}$} \\
\hline
\end{tabular}

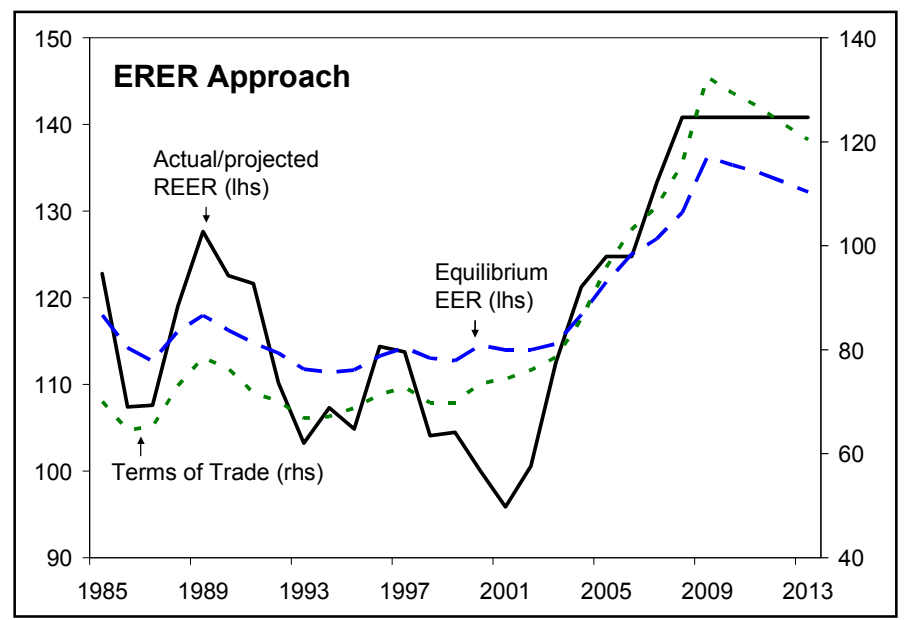




\section{The staff and authorities agreed that there are a number of factors mitigating} the external vulnerability. These include the limited currency risk associated with the foreign debt, the sound banking system, and the strong economic policy and financial supervision frameworks. About 40 percent of gross foreign debt is in Australian dollars, with half of the remainder in U.S. dollars. Survey data suggests the bulk of the foreign-currencydenominated debt is hedged against currency risk. Moreover, less than 10 percent of the gross debt is with the public sector, leaving most of the debt with financial institutions (Table 6). Australia's current account deficits largely reflect high investment rather than low saving, and should be sustainable as long as investment leads to growth in export capacity. ${ }^{4}$

\section{Fiscal Policy}

19. Fiscal policy, focused on medium-term sustainability, delivered a sequence of surpluses that eliminated Commonwealth net debt. This leaves Australia with an enviable fiscal position by international standards. The new Labor government aims to maintain a conservative fiscal strategy by focusing on three objectives:

- $\quad$ achieving budget surpluses, on average, over the medium term;

- $\quad$ keeping tax as a share of GDP, on average, below the 2007/08 level (currently estimated at 24.7 percent); and

- $\quad$ improving the government's net financial worth over the medium term.

20. In the near term, the authorities stressed that the latest budget places priority on helping to fight inflation and reprioritizing spending to build capacity. The 2008/09 budget slows the pace of growth of Commonwealth government expenditure and forecasts an increase in the underlying cash surplus to 1.8 percent of GDP. This stance is slightly contractionary, with the staff's estimate of the structural balance increasing by $1 / 4$ percent of GDP, broadly in line with the change in the underlying cash surplus (Figure 11). The budget saves about half of the revenue surprise from the jump in the terms of trade and higher nominal GDP. ${ }^{5}$ The remainder of the revenue surprise helps fund personal income tax cuts targeted at lower income earners. Some other tax increases and expenditure cuts finance new initiatives for health, education, climate change, and housing. Beyond 2008/09, spending is projected to pick up and the underlying cash surplus is expected to fall slightly over the next four years.

\footnotetext{
4 “Australia's Large and Sustained Current Account Deficits: Should Consenting Adults be Trusted?" IMF Country Report No: 06/373 (10/23/06).

${ }^{5}$ For outer years, about $1 / 3$ of the revenue surprise is saved. The revenue surprise is calculated using the May 2007 budget projections as the baseline.
} 
Figure 11. Australia: Fiscal Forecast

The commonwealth is expected to continue to run surpluses...

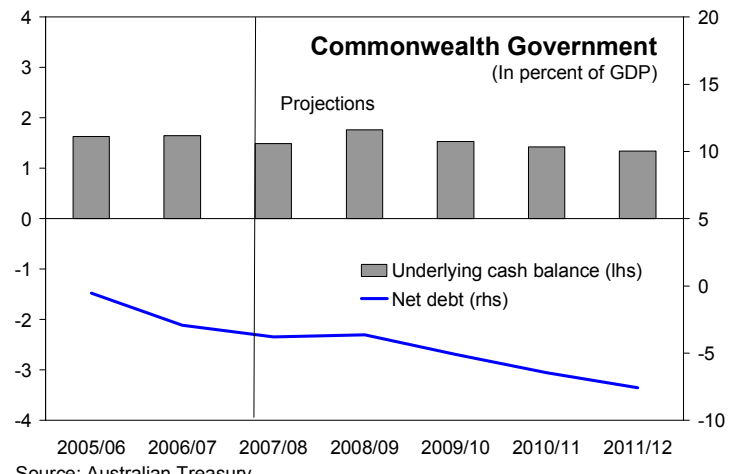
Source: Australian Treasury.

Real expenditure growth is expected to slow in 2008/09 and pick up thereafter.

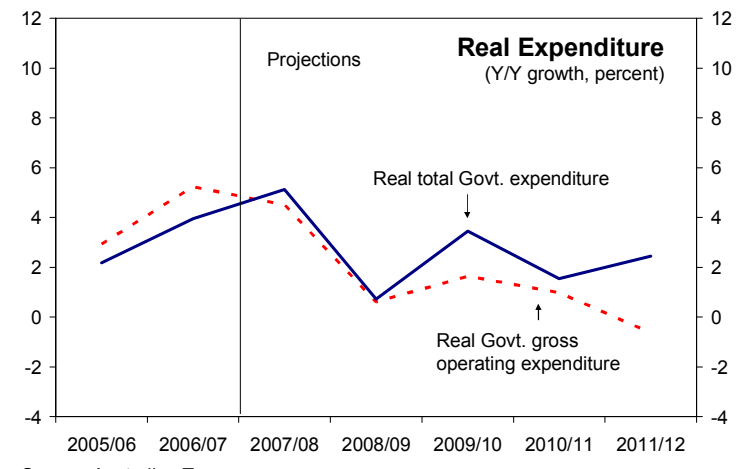

...with a small increase in the surplus in 2008/09 followed by small decreases in outer years.

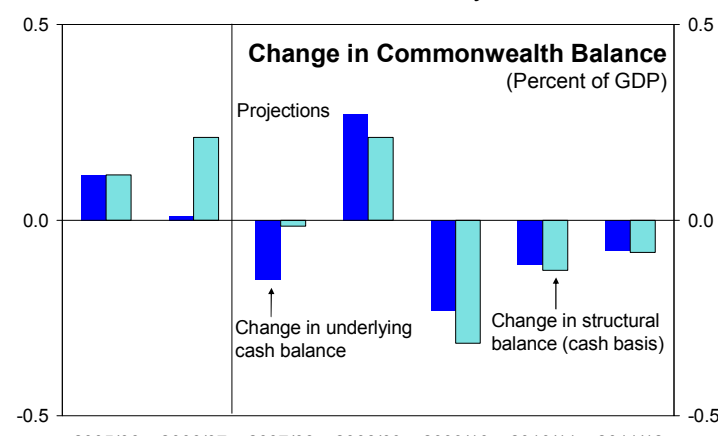

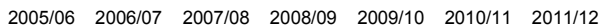
Source: Australian Treasury and Fund Staff calculations

While states are projected to run small deficits over the next three years.

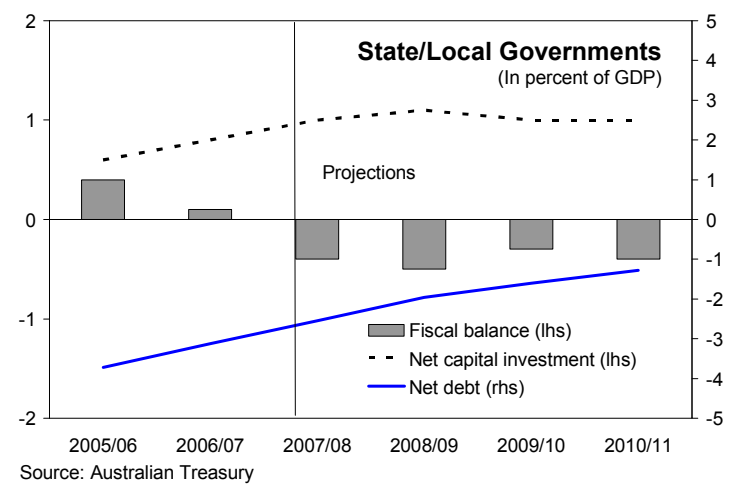

\section{The surpluses for $2007 / 08$ and $2008 / 09$ will be saved in three new funds for} infrastructure, health, and education to finance capital spending. About 3 percent of GDP will be contributed to the funds, depending on the final budget outcomes and spending from the funds is included in the budget. The funds are a means to constrain spending revenue from the commodity boom in the near term, by saving for infrastructure spending over the medium to long term.

22. The staff advised that further fiscal restraint may be needed. The staff encouraged the authorities to identify areas where additional spending cuts can be implemented and to save any positive revenue surprises to assist monetary policy, until it is clear that inflation will decline. Given the uncertainty about how much of the increase in commodity prices will be permanent, saving the additional revenue in the near term may avoid sharp changes in taxes and spending in the future. Moreover, state governments are expected to run deficits and increase infrastructure spending, offsetting restraint at the Commonwealth level. 
23. The authorities stated that if inflation pressures persist they would take the necessary action to support monetary policy. They noted that the next budget would offer another chance to constrain spending and direct it toward areas that are more productive, such as education, health, and infrastructure. They also emphasized that they are committed to saving any further positive revenue surprises in 2008/09. If there is a positive revenue surprise in the 2009/2010 Budget and inflation remains high, the authorities indicated that they would maintain tight controls on spending.

24. To the extent that the improvement in the budget balance is structural, associated with permanently higher commodity prices, there should be scope to reduce taxes or increase spending over the medium term. Staff analysis suggests that a combination of lower labor and capital income taxes, along with increased public investment, will generate the largest economic gains. ${ }^{6}$ The gains from other options such as lower consumption taxes or higher public consumption are not as large. Despite the expected structural improvement in the medium term, significant long-term fiscal challenges remain, particularly in the area of healthcare spending, and early adjustments will be key to preserving fiscal sustainability. ${ }^{7}$

25. The authorities noted that there would be scope to reform taxation and increase spending in priority areas, if the recent gains in commodity export prices prove to be permanent. The budget projections assume some easing in commodity prices over the medium term from the record levels forecast for 2008/09. Nevertheless, in recent years the authorities have been surprised by revenue on the upside, and commodity prices may not ease as expected. The authorities made it clear that any changes in taxes and spending would be consistent with the new government's medium-term fiscal objectives, thereby further strengthening the fiscal position.

\section{Dealing with the Global Financial Market Turmoil}

26. The RBA responded promptly and fittingly to the domestic impact of the global financial market turmoil. The RBA provided the necessary liquidity support to banks through exchange settlement accounts and increased the range of securities accepted for repo lending in late 2007, including residential-mortgage-backed securities. Since then, many banks have securitized mortgages and are holding them on their books as a contingency measure in case they need to obtain liquidity from the RBA.

27. The Australian Prudential Regulation Authority (APRA) also reacted in a timely and appropriate manner. APRA intensified its monitoring of asset quality, capital

\footnotetext{
${ }^{6}$ Using the IMF's GIMF model, the accompanying Selected Issues paper examines the macroeconomic consequences of alternative strategies for dealing with increased revenue from the commodity boom.

${ }^{7}$ The 2007 Intergenerational Report (Australian Treasury) lays out the long-term fiscal projections.
} 
adequacy, and the liability structure of banks. In the context of Basel II, APRA is working with large banks on stress tests, which include extreme scenarios such as the loss of access to offshore credit markets for an extended period.

28. In addition, banks are adjusting the structure of their funding in response to the turmoil. They are increasing liquidity as well as lengthening the maturity of their funding and diversifying the sources. However, the banks have found it costly to extend the maturity because of higher interest rates for term funding and have made limited progress in reducing the rollover risk associated with their short-term wholesale funding. Staff analysis using extreme stress test scenarios applied to the large banks suggests that they could suffer a significant fall in profits from an increase in funding costs associated with loss of access to offshore markets for 90 days, but that their capital would remain adequate. ${ }^{8}$

29. The introduction of new liquidity guidelines should further encourage banks to reduce their rollover risk. APRA plans to introduce liquidity guidelines with a focus on improved disclosure and stress testing. The aim should be to encourage banks to reduce the risk of disruptions from restricted access to wholesale markets by diversifying their funding sources, lengthening the maturity of their funding, and holding sufficient liquidity. The staff advised that requiring banks to publish more detail on the maturity structure of their funding, especially from offshore markets, would impose additional discipline.

30. Banks are exposed to households, but appear resilient to an increase in default rates on mortgages. Households have become increasingly indebted, with debt reaching almost 160 percent of disposable income and debt-servicing costs at about 14 percent of disposable income. As more than half of banks' loans are mortgages, banks' asset quality would likely deteriorate with a large increase in interest rates, rise in unemployment, or fall in house prices. Staff analysis show that a very large increase in default rates (to 10 percent of all housing loans) would be required to reduce capital ratios of the four major banks below 8 percent. ${ }^{9}$ Moreover, staff estimates suggest that house prices are only moderately overvalued (5-15 percent) and that continued strong immigration and household income growth could increase equilibrium house prices.

31. The failure resolution and crisis management framework is being strengthened, as recommended in the 2006 Financial Sector Assessment Program (FSAP). The proposed Financial Claims Scheme is a key element of legislation to be introduced to parliament, and it would provide depositors of a failed authorized deposit taking institution

\footnotetext{
${ }^{8}$ A selected issues paper examines the major banks' rollover risks. It also analyzes house prices and the risks associated with banks' exposure to housing.

${ }^{9}$ A 10 percent default rate on all mortgage loans would require a default on about half of mortgages with loan to value ratios of over 80 percent.
} 
32. with early access to their funds. ${ }^{10}$ In addition, the interdependence of the Australian and New Zealand banking systems underscores the importance of the planned work on the practical aspects of coordination of crisis management. Good progress has also been made on a number of other FSAP recommendations (Table 7).

\section{The authorities are also addressing other supervisory and regulatory issues} identified as a result of the turmoil. The government intends to ensure a comprehensive national approach to regulating a number of credit-related financial services. ${ }^{11}$ These include mortgage brokers, trustee corporations, and property investment advisors. In addition, the authorities are following up on the recommendations of the Financial Stability Forum Report on enhancing the resilience of financial markets and financial institutions. ${ }^{12}$ In particular, APRA will strengthen the capital treatment of structured credit and securitization activities, and is working on updating the risk parameters and other provisions of the Basel II framework. The authorities are also encouraging banks to strengthen their risk disclosure to the market.

\section{Implementing Further Structural Reform}

\section{The Commonwealth and state governments have set an ambitious reform} agenda. Areas of reform include taxation, emissions trading, healthcare, education, infrastructure, business regulation, and labor relations (Box 4). The Commonwealth government is working with the states on these reforms through an invigorated Council of Australian Governments that meets quarterly. Reform at the state level is important as they provide most of the health, education, and infrastructure services and administer some taxes and business regulations. Differences exist among the states in these areas, which presents a barrier to the movement of labor and capital across state boundaries in some industries and hinders national competition. The aim of the reforms is to raise productivity and labor force participation, including by reducing barriers to competition and the movement of resources.

\section{The staff agreed with the need for broad-based reform and noted that} governments should follow through on their commitments. Recent work by the staff shows that the Australia's productivity performance has been boosted by earlier structural

\footnotetext{
10 The proposed scheme would provide depositors of failed authorized deposit-taking institutions with timely access to the first \$A20,000 of their funds, and policyholders of a failed general insurer with a right to have claims met.

${ }^{11}$ The details can be found in the Green Paper on Financial Services and Credit Reform (June 2008), http://www.treasury.gov.au/contentitem.asp?NavId=037\&ContentID=1381.

${ }^{12}$ For more details see: http://www.treasurer.gov.au/DisplayDocs.aspx?doc=pressreleases/2008/063.htm\&pageID=003\&min=wms\&Ye $\underline{\mathrm{ar}=\& \text { DocType }=0 \text {. }}$
} 


\section{Box 4. Structural Reform Agenda}

\section{The Commonwealth and state governments have a wide-ranging structural reform agenda, which is summarized below:}

Tax Reform. A broad-ranging review of the tax system is underway that covers all taxes, social security and transfer payments by the Commonwealth and the states, excluding the goods and service tax (GST). The aim is to improve the tax and transfer system so as to minimize distortions, enhance international competitiveness, and reduce complexity.

Commonwealth-State Financial Relations. A new model for Commonwealth-state financial relations is being developed, with priority given to streamlining payments by the Commonwealth for specific purposes and creating new incentive payments to states to energize reforms. These reforms are aimed at clarifying roles and responsibility, reducing duplication and waste, and enhancing accountability.

Emissions Trading. The new government has ratified the Kyoto Protocol and plans to put in place a 'cap and trade' emissions trading scheme. It will set an overall environmental cap by issuing a set number of permits, and then allow entities to trade permits, thereby putting a price on carbon.

Healthcare. The government is developing a new national healthcare agreement, which encompasses preventative health, primary care, aged care, and hospitals. The agreement will clarify the roles and responsibilities of all levels of government in the provision of healthcare. The government will establish a Health and Hospital Fund (\$A10 billion) for investment in health facilities.

Education. Substantial reform of Australia's education and training system is being planned to raise educational standards. The government intends to establish an Education Investment Fund (\$A11 billion) to help build education facilities.

Infrastructure. A federal advisory council has been established to develop a blueprint for unlocking infrastructure bottlenecks in transport, water, energy, and communications. In addition, the government intends to establish a Building Australia Fund (\$A20 billion) to help finance key projects.

Business regulation and competition. Priority areas include national harmonization of occupational health and safety law; national systems for trade and professional qualifications and licensing; and reforms to pricing of energy, transport, and water.

Water management. The government has introduced a new ten-year \$A12.9 billion national water policy framework to address urban and rural water challenges. Reforms in the MurrayDarling river basin include implementation of a new governance arrangement and the intention to purchase water entitlements from willing sellers.

Labor relations. The government plans to modernize and simplify the system of awards (i.e., agreements on conditions of work). The emphasis will remain on collective bargaining at the enterprise level, with Australian Workplace Agreements (individual contracts that cover less than 3 percent of the private sector workforce) being phased out. Individuals will still be able to negotiate individual contracts. 
reforms. ${ }^{13}$ Successful implementation of further reforms would enhance the economy's flexibility, lift productivity, and foster labor force participation. Reform is essential to take full advantage of the mining boom that is centered on Queensland and Western Australia, that will require capital and labor to move from other states.

\section{StAFF APPRAISAL}

36. The outlook is for real GDP growth to slow over the next two years, as needed to reduce inflation. Higher debt-service costs, tighter credit conditions, and a decline in confidence should deliver the required slowing in domestic demand. But upside risks to growth and inflation stem from the extraordinary jump in export prices for commodities, which will boost the terms of trade by 20 percent in 2008/09.

37. A firm monetary policy stance is essential to reduce inflation. The RBA raised the cash rate appropriately in the past year as inflation increased to the highest level in more than a decade. Looking ahead, the authorities should act quickly to tighten monetary policy further if leading indicators suggest that domestic demand will not slow as expected or the outlook for inflation deteriorates. The inflation-targeting framework remains a suitable approach because it helps anchor medium-term inflation expectations, making it easier to reduce inflation in the face of higher commodity prices.

38. The flexible exchange rate policy is appropriate and the appreciation in recent years has eased inflation pressures. The Australian dollar is temporarily above its long-run equilibrium level, but is likely to fall back toward equilibrium over time as the RBA reduces the cash rate once it is clear that inflation will moderate.

39. Fiscal policy is providing support for monetary policy, but further restraint may be needed. The reduction in public spending growth in the latest budget will help reduce inflation, and the intention to save any further positive revenue surprises in 2008/09 will allow the automatic stabilizers to work. Nevertheless, additional fiscal restraint may be needed to take pressure off monetary policy in light of the upside risks to inflation. To the extent that the improvement in the budget balance is structural, associated with permanently higher commodity prices, there should be scope to reduce taxes or increase spending over the medium term.

40. Australia's banking system is sound, but some vulnerabilities remain. The authorities' response to the credit market turmoil has been timely and fitting, with the RBA providing liquidity support and APRA intensifying its monitor of banks. The four large banks remain profitable and well capitalized, but the turmoil highlighted their vulnerability to rollover risks arising from short-term wholesale funding. The planned introduction of

13 “Does Technology Diffusion Explain Australia's Productivity Performance," Thierry Tressel, IMF Working Paper 08/4, January 2008. 
liquidity guidelines will be helpful to reduce the risk of disruptions arising from loss of access to offshore funding. Requiring the publication of more detail on the maturity structure of banks' funding, especially from offshore markets, would also encourage banks to reduce their exposure to rollover risk.

41. The authorities should seize the window of opportunity provided by Australia's robust economic performance and the strong fiscal position to advance structural

reforms. If implemented fully, the broad reform agenda should enhance the flexibility of the economy and lift productivity and labor force participation.

42. It is proposed that the next Article IV consultation with Australia take place on the standard 12-month cycle. 
Table 1. Australia: Selected Economic Indicators, 2004-09

Nominal GDP (2007): \$A 1,084 billion (US\$911 billion)

Quota (in millions): SDR 3,237

GDP per capita (2007): US $\$ 43,341$

Population (December 2007): 21.1 million

\begin{tabular}{|c|c|c|c|c|c|c|}
\hline & 2004 & 2005 & 2006 & 2007 & $\begin{array}{c}2008 \\
\text { Proj. }\end{array}$ & $\begin{array}{r}2009 \\
\text { Proj. }\end{array}$ \\
\hline \multicolumn{7}{|l|}{ Output and demand (percent change) } \\
\hline Real GDP & 3.9 & 2.9 & 2.7 & 4.3 & 2.7 & 2.8 \\
\hline Total domestic demand & 5.9 & 4.4 & 3.1 & 5.9 & 4.1 & 3.1 \\
\hline Private consumption & 5.9 & 3.0 & 3.1 & 4.6 & 3.9 & 2.9 \\
\hline Total investment & 8.0 & 8.0 & 5.2 & 8.5 & 6.2 & 4.9 \\
\hline Business & 13.0 & 15.2 & 8.0 & 12.0 & 7.5 & 7.0 \\
\hline Dwelling & 3.0 & -3.5 & -2.4 & 3.1 & 0.2 & 0.7 \\
\hline Net exports $1 /$ & -1.9 & -1.3 & -0.9 & -1.7 & -1.6 & -0.2 \\
\hline \multicolumn{7}{|l|}{ Inflation and unemployment (in percent) } \\
\hline CPI inflation & 2.3 & 2.7 & 3.5 & 2.3 & 4.4 & 3.5 \\
\hline Unemployment rate & 5.4 & 5.1 & 4.8 & 4.4 & 4.2 & 4.7 \\
\hline \multicolumn{7}{|l|}{ Saving and investment (in percent of GDP) } \\
\hline Gross national saving & 20.2 & 20.9 & 21.6 & 22.2 & 21.5 & 22.5 \\
\hline General government saving & 3.6 & 4.3 & 5.0 & 4.1 & 4.6 & 4.4 \\
\hline Private saving $2 /$ & 16.6 & 16.6 & 16.6 & 18.1 & 16.9 & 18.1 \\
\hline Gross capital formation & 26.1 & 27.0 & 26.6 & 27.9 & 27.7 & 26.7 \\
\hline \multicolumn{7}{|l|}{ Fiscal indicators (cash basis, in percent of GDP) 3/ } \\
\hline Receipts & 25.9 & 26.3 & 26.5 & 26.0 & 26.2 & 25.4 \\
\hline Payments & 24.9 & 24.8 & 24.8 & 24.2 & 24.4 & 23.4 \\
\hline Underlying cash balance & 1.0 & 1.5 & 1.6 & 1.6 & 1.5 & 1.8 \\
\hline \multicolumn{7}{|l|}{ Money and credit (end of period) } \\
\hline Interest rate (90-day bill, in percent) 4 / & 5.4 & 5.6 & 6.4 & 7.2 & 7.8 & $\ldots$ \\
\hline Treasury bond yield (10-year, in percent) $4 /$ & 5.3 & 5.2 & 5.9 & 6.3 & 6.5 & $\ldots$ \\
\hline M3 (percent change) $4 /$ & 8.9 & 8.2 & 13.0 & 22.5 & 19.6 & $\ldots$ \\
\hline Private domestic credit (percent change) $4 /$ & 14.1 & 13.5 & 14.2 & 17.2 & 14.6 & $\ldots$ \\
\hline \multicolumn{7}{|l|}{ Balance of payments (in percent of GDP) } \\
\hline Current account & -6.0 & -5.8 & -5.5 & -6.1 & -6.1 & -4.2 \\
\hline Of which: Trade balance & -2.8 & -1.9 & -1.3 & -1.9 & -1.6 & 1.4 \\
\hline Foreign direct investment (net) & 3.9 & -0.2 & 0.4 & -0.2 & 0.7 & 0.4 \\
\hline Terms of trade (percent change) & 9.3 & 11.7 & 7.6 & 4.3 & 7.2 & 13.8 \\
\hline \multicolumn{7}{|l|}{ External assets and liabilities (in percent of GDP) } \\
\hline Net external liabilities & 55.5 & 56.8 & 60.2 & 66.5 & 66.6 & 65.3 \\
\hline Net external debt & 47.5 & 50.0 & 52.0 & 55.8 & 56.3 & 55.1 \\
\hline Gross official reserves 4/ & 5.5 & 6.3 & 6.9 & 2.8 & 3.0 & $\ldots$ \\
\hline Net official reserves $4 /$ & 2.9 & 3.1 & 3.1 & 3.3 & 3.0 & $\cdots$ \\
\hline \multicolumn{7}{|l|}{ Exchange rate (period average) } \\
\hline U.S. dollar/Australian dollar 4/ & 0.74 & 0.76 & 0.75 & 0.84 & 0.93 & $\ldots$ \\
\hline Trade-weighted index 4/ & 62.3 & 63.9 & 63.0 & 67.5 & 70.5 & $\ldots$ \\
\hline Real effective exchange rate $5 /$ & 121.2 & 124.8 & 124.7 & 133.3 & 137.7 & $\ldots$ \\
\hline \multicolumn{7}{|l|}{ Memorandum Item: } \\
\hline Nominal GDP (in billions of Australian dollar) & 869 & 935 & 1,005 & 1,088 & 1,173 & 1,279 \\
\hline
\end{tabular}

Sources: Data provided by the Australian authorities; and Fund staff estimates and projections.

1/ Contribution to growth

2/ Includes public trading enterprises.

3/ Fiscal year ending June 30, Commonwealth Budget.

4/ Data for 2008 are for latest available month.

5/ IMF, Information Notice System index $(1990=100)$. 
Table 2. Australia: Fiscal Accounts, 2004/05-2011/121/

(In percent of GDP)

\begin{tabular}{|c|c|c|c|c|c|c|c|c|}
\hline & \multirow[b]{2}{*}{$2004 / 05$} & \multirow[b]{2}{*}{$2005 / 06$} & \multirow[b]{2}{*}{ 2006/07 } & \multirow[b]{2}{*}{$\begin{array}{c}2007 / 08 \\
\text { Est. }\end{array}$} & \multicolumn{4}{|c|}{ Projections 2/ } \\
\hline & & & & & $2008 / 09$ & $2009 / 10$ & $2010 / 11$ & $2011 / 12$ \\
\hline \multicolumn{9}{|l|}{ Fiscal accounts on an accrual basis $3 /$} \\
\hline \multicolumn{9}{|l|}{ Commonwealth government } \\
\hline Revenue & 27.0 & 27.0 & 26.6 & 26.9 & 25.9 & 26.2 & 26.2 & 26.1 \\
\hline Tax & 25.6 & 25.4 & 25.1 & 25.4 & 24.3 & 24.7 & 24.6 & 24.4 \\
\hline Income tax & 18.2 & 18.2 & 18.1 & 18.5 & 17.6 & 18.0 & 18.0 & 17.9 \\
\hline Individuals and other withholdings & 12.1 & 11.8 & 11.2 & 11.1 & 10.3 & 10.3 & 10.5 & 10.3 \\
\hline Indirect and other tax & 7.5 & 7.2 & 7.0 & 6.9 & 6.7 & 6.7 & 6.6 & 6.6 \\
\hline Nontax & 1.4 & 1.6 & 1.5 & 1.5 & 1.6 & 1.6 & 1.6 & 1.6 \\
\hline Expenses & 25.5 & 25.0 & 24.7 & 24.9 & 23.8 & 24.2 & 24.1 & 24.1 \\
\hline Salaries and wages & 1.3 & 1.3 & 1.3 & 1.3 & 1.2 & 1.2 & 1.2 & 1.1 \\
\hline Goods and services & 5.0 & 5.0 & 4.9 & 4.7 & 4.5 & 4.5 & 4.5 & 4.4 \\
\hline Current transfers & 17.0 & 16.7 & 16.2 & 16.3 & 15.6 & 16.0 & 16.1 & 16.3 \\
\hline Other expenses & 2.3 & 2.2 & 2.4 & 2.6 & 2.5 & 2.4 & 2.3 & 2.3 \\
\hline Net capital investment & 0.1 & 0.3 & 0.2 & 0.3 & 0.3 & 0.3 & 0.3 & 0.4 \\
\hline Fiscal balance 4/ & 1.4 & 1.7 & 1.6 & 1.8 & 1.9 & 1.7 & 1.7 & 1.6 \\
\hline State, Territory, and local government balance & 0.4 & 0.4 & 0.1 & -0.4 & -0.5 & -0.3 & -0.4 & $\ldots$ \\
\hline Public nonfinancial corporations balance 5/ & -0.3 & -1.0 & -0.8 & -1.6 & -1.6 & $\ldots$ & $\ldots$ & $\ldots$ \\
\hline Nonfinancial public sector balance & 1.5 & 1.2 & 0.9 & -0.2 & -0.2 & $\cdots$ & $\cdots$ & $\cdots$ \\
\hline \multicolumn{9}{|l|}{ Fiscal accounts on a cash basis } \\
\hline \multicolumn{9}{|l|}{ Commonwealth government } \\
\hline Receipts (including Future Fund earnings) & 26.3 & 26.5 & 26.0 & 26.2 & 25.4 & 25.7 & 25.7 & 25.5 \\
\hline Payments & 24.8 & 24.8 & 24.2 & 24.4 & 23.4 & 23.9 & 24.0 & 23.9 \\
\hline Future Fund earnings & $\ldots$ & 0.0 & 0.2 & 0.3 & 0.3 & 0.2 & 0.2 & 0.2 \\
\hline Underlying cash balance $6 /$ & 1.5 & 1.6 & 1.6 & 1.5 & 1.8 & 1.5 & 1.4 & 1.3 \\
\hline \multicolumn{9}{|l|}{ Memorandum items: } \\
\hline Commonwealth government net debt $7 /$ & 1.4 & -0.6 & -2.9 & -3.8 & -3.7 & -5.1 & -6.5 & -7.6 \\
\hline Commonwealth government net worth $8 /$ & 1.7 & 2.6 & 4.3 & 5.4 & 7.0 & 8.7 & 10.3 & 11.7 \\
\hline Commonwealth government financial net worth 9/ & -7.4 & -6.6 & -4.8 & -2.3 & -0.3 & 1.4 & 3.0 & 4.4 \\
\hline
\end{tabular}

Sources: Commonwealth of Australia: Budget Strategy and Outlook, 2008-09.

1/ Fiscal year ends June 30.

2/ Projections as presented in the Budget Strategy and Outlook, 2008-09.

3/ Accrual data are reported on a consistent basis with Government Financial Statistics (GFS).

4/ The fiscal balance is equal to revenue less expenses and net capital investment.

$5 /$ The consolidated commonwealth, state, and local governments.

6/ Underlying cash balance equals receipts less payments, and excludes earnings of the Future Fund.

$7 /$ Includes Future Fund assets that are kept in cash and debt instruments.

$8 /$ Includes financial and nonfinancial assets and total liabilities, including Future Fund assets and unfunded superannuation liabilities to public employees.

9/ Includes financial assets and total liabilities, including Future Fund assets and unfunded superannuation liabilities to public employees. 
Table 3. Australia: Balance of Payments, 2004-09

(In percent of GDP)

\begin{tabular}{|c|c|c|c|c|c|c|}
\hline & 2004 & 2005 & 2006 & 2007 & $\begin{array}{l}\text { Proj. } \\
2008\end{array}$ & $\begin{array}{l}\text { Proj. } \\
2009\end{array}$ \\
\hline Current account balance & -6.0 & -5.8 & -5.5 & -6.1 & -6.1 & -4.2 \\
\hline Goods balance & -2.8 & -1.9 & -1.3 & -1.9 & -1.6 & 1.4 \\
\hline Exports & 13.6 & 15.0 & 16.5 & 15.6 & 16.6 & 19.1 \\
\hline Imports & -16.4 & -16.9 & -17.8 & -17.5 & -18.2 & -17.7 \\
\hline Net services & 0.1 & 0.1 & 0.1 & 0.2 & 0.1 & 0.1 \\
\hline Total credits & 4.4 & 4.4 & 4.4 & 4.4 & 4.3 & 4.4 \\
\hline Total debits & -4.4 & -4.3 & -4.3 & -4.2 & -4.2 & -4.2 \\
\hline Net income & -3.3 & -3.9 & -4.3 & -4.4 & -4.6 & -5.7 \\
\hline Of which: Net interest payments & -1.6 & -1.7 & -2.2 & -2.3 & -2.9 & -3.8 \\
\hline Of which: Net equity income & -1.5 & -2.1 & -2.0 & -1.9 & -1.7 & -1.9 \\
\hline Net transfers & -0.1 & -0.1 & -0.1 & 0.0 & 0.0 & 0.0 \\
\hline Capital and financial account & 6.1 & 5.8 & 5.5 & 6.2 & 6.1 & 4.2 \\
\hline Capital account & 0.2 & 0.2 & 0.2 & 0.2 & 0.2 & 0.2 \\
\hline Financial account & 6.0 & 5.7 & 5.3 & 6.0 & 5.8 & 4.0 \\
\hline Direct investment transactions (net) & 3.9 & -0.2 & 0.4 & -0.2 & 0.7 & 0.4 \\
\hline Equity (net) & 3.5 & -1.0 & -0.6 & -1.1 & -1.0 & -0.7 \\
\hline Debt (net) & 0.4 & 0.8 & 1.0 & 0.9 & 1.7 & 1.1 \\
\hline Portfolio investment transactions (net) & 2.6 & 5.3 & 6.9 & 0.5 & 5.1 & 2.9 \\
\hline Equity (net) & -5.5 & 0.0 & -1.2 & -2.4 & -1.0 & -1.1 \\
\hline Debt (net) & 8.1 & 5.3 & 8.2 & 2.9 & 6.0 & 3.9 \\
\hline Financial derivatives (net) & 0.1 & 0.0 & 0.3 & -1.3 & -0.4 & -0.9 \\
\hline Other transactions (net) & -0.6 & 0.6 & -2.4 & 7.0 & 0.4 & 1.6 \\
\hline Net errors and omissions & -0.1 & -0.1 & -0.1 & -0.1 & 0.0 & 0.0 \\
\hline & \multicolumn{6}{|c|}{ (Assets and liabilities at end-period) } \\
\hline Net external liabilities & 55.5 & 56.8 & 60.2 & 66.5 & 66.6 & 65.3 \\
\hline Net external equity liabilities & 8.0 & 6.8 & 8.1 & 10.7 & 10.4 & 10.1 \\
\hline Foreign equity investment in Australia & 54.9 & 50.7 & 56.2 & 61.0 & $\ldots$ & $\ldots$ \\
\hline Australian equity investment abroad & -46.9 & -43.9 & -48.1 & -50.3 & $\ldots$ & $\ldots$ \\
\hline Net external debt & 47.5 & 50.0 & 52.0 & 55.8 & 56.3 & 55.1 \\
\hline Net public sector & 1.6 & 1.0 & 0.2 & 3.6 & $\ldots$ & $\ldots$ \\
\hline Net private sector & 45.9 & 49.0 & 51.8 & 52.2 & $\ldots$ & $\ldots$ \\
\hline Gross external debt & 79.8 & 82.3 & 90.3 & 91.1 & $\ldots$ & $\ldots$ \\
\hline Of which: Australian dollar-denominated & 28.4 & 30.1 & 33.6 & 38.9 & $\ldots$ & $\ldots$ \\
\hline Gross external lending & -32.3 & -32.2 & -38.3 & -35.3 & $\ldots$ & $\ldots$ \\
\hline Short-term net external debt (residual maturity basis) & 17.8 & 19.3 & 19.2 & 25.5 & $\ldots$ & $\ldots$ \\
\hline Short-term gross external debt & 36.9 & 37.1 & 39.9 & 42.4 & $\ldots$ & $\ldots$ \\
\hline Short-term gross external lending & -19.1 & -17.8 & -20.7 & -16.8 & $\ldots$ & $\ldots$ \\
\hline \multicolumn{7}{|l|}{ Memorandum items: } \\
\hline Gross official reserves (in billions of Australian dollars) & 47.4 & 59.0 & 69.6 & 30.5 & $\ldots$ & $\ldots$ \\
\hline RBA outstanding forward contracts (in billions of $\$ \mathrm{~A}$ ) & 22.4 & 30.4 & 38.9 & -5.2 & $\ldots$ & $\ldots$ \\
\hline Net official reserves (in billions of Australian dollars) & 25.0 & 28.6 & 30.7 & 35.7 & $\ldots$ & $\ldots$ \\
\hline Gross reserves in months of imports & 3.2 & 3.6 & 3.8 & 1.5 & $\ldots$ & $\ldots$ \\
\hline Net official reserves in months of imports & 1.7 & 1.7 & 1.7 & 1.8 & & \\
\hline Gross reserves to ST FX denominated debt (percent) & 21.5 & 24.7 & 24.1 & 10.7 & $\ldots$ & $\ldots$ \\
\hline Net interest payments to exports (percent) & 9.1 & 8.8 & 10.3 & 11.5 & $\ldots$ & $\ldots$ \\
\hline
\end{tabular}

Sources: Data provided by the Australian authorities; and Fund staff estimates and projections. 
Table 4. Australia: Balance of Payments in U.S. Dollars, 2004-07 (In billions of U.S. dollars)

\begin{tabular}{|c|c|c|c|c|}
\hline & 2004 & 2005 & 2006 & 2007 \\
\hline Current account balance & -38.6 & -41.3 & -41.7 & -55.7 \\
\hline Goods balance & -17.9 & -13.7 & -9.9 & -17.3 \\
\hline Exports & 87.1 & 106.8 & 124.7 & 142.4 \\
\hline Imports & -105.0 & -120.5 & -134.7 & -159.7 \\
\hline Net services & 0.5 & 0.5 & 0.9 & 1.7 \\
\hline Total credits & 28.5 & 31.0 & 33.1 & 40.3 \\
\hline Total debits & -27.9 & -30.5 & -32.2 & -38.6 \\
\hline Net income & -20.9 & -27.6 & -32.2 & -39.7 \\
\hline Of which: Net interest payments & -10.5 & -12.2 & -16.3 & -21.1 \\
\hline Of which: Net equity income & -9.9 & -14.8 & -14.8 & -17.3 \\
\hline Net transfers & -0.3 & -0.5 & -0.4 & -0.3 \\
\hline Capital and financial account & 39.3 & 41.6 & 41.9 & 56.4 \\
\hline Capital account & 1.1 & 1.2 & 1.7 & 1.7 \\
\hline Financial account & 38.2 & 40.3 & 40.2 & 54.8 \\
\hline Direct investment transactions (net) & 25.2 & -1.8 & 3.1 & -1.9 \\
\hline Equity (net) & 22.4 & -7.3 & -4.8 & -9.9 \\
\hline Debt (net) & 2.7 & 5.5 & 7.9 & 8.0 \\
\hline Portfolio investment transactions (net) & 16.5 & 37.8 & 52.6 & 5.0 \\
\hline Equity (net) & -35.3 & -0.2 & -9.2 & -21.5 \\
\hline Debt (net) & 51.8 & 38.1 & 61.8 & 26.4 \\
\hline Financial derivatives (net) & 0.4 & 0.0 & 2.4 & -12.2 \\
\hline Other transactions (net) & -3.8 & 4.3 & -17.9 & 64.0 \\
\hline \multirow[t]{2}{*}{ Net errors and omissions } & -0.4 & -0.6 & -0.5 & -0.5 \\
\hline & \multicolumn{4}{|c|}{ (Assets and liabilities at end-period) } \\
\hline Net external liabilities & 355.6 & 404.7 & 455.5 & 606.7 \\
\hline Net external equity liabilities & 51.4 & 48.3 & 61.5 & 97.5 \\
\hline Foreign equity investment in Australia & 351.6 & 361.5 & 425.5 & 556.6 \\
\hline Australian equity investment abroad & -300.2 & -313.1 & -364.0 & -459.1 \\
\hline Net external debt & 304.2 & 356.4 & 394.0 & 509.2 \\
\hline Net public sector & 10.1 & 7.1 & 1.8 & 32.6 \\
\hline Net private sector & 294.1 & 349.2 & 392.2 & 476.6 \\
\hline Gross external debt & 511.3 & 586.1 & 683.9 & 831.0 \\
\hline Of which: Australian dollar-denominated & 181.9 & 214.3 & 254.4 & 354.6 \\
\hline Gross external lending & -207.1 & -229.7 & -289.9 & -321.8 \\
\hline Short-term net external debt (residual maturity basis) & 114.0 & 137.5 & 145.4 & 233.1 \\
\hline Short-term gross external debt & 236.3 & 264.3 & 302.4 & 386.8 \\
\hline Short-term gross external lending & -122.3 & -126.8 & -157.0 & -153.7 \\
\hline
\end{tabular}

Sources: Data provided by the Australian authorities; and Fund staff estimates. 
Table 5. Australia: Medium-Term Scenario, 2007-13

\begin{tabular}{|c|c|c|c|c|c|c|c|c|}
\hline & \multirow{2}{*}{$\begin{array}{r}\text { Average } \\
1997-2006\end{array}$} & \multirow[b]{2}{*}{2007} & \multicolumn{6}{|c|}{ Projections } \\
\hline & & & 2008 & 2009 & 2010 & 2011 & 2012 & 2013 \\
\hline \multicolumn{9}{|l|}{ Real economic indicators (percent change) } \\
\hline GDP & 3.6 & 4.3 & 2.7 & 2.8 & 3.2 & 3.3 & 3.4 & 3.3 \\
\hline Total domestic demand & 4.5 & 5.9 & 4.1 & 3.1 & 3.5 & 3.4 & 3.3 & 3.3 \\
\hline Private consumption & 3.9 & 4.6 & 3.9 & 2.9 & 2.9 & 2.9 & 2.8 & 2.7 \\
\hline Total investment & 6.6 & 8.5 & 6.2 & 4.9 & 5.0 & 4.8 & 4.8 & 4.7 \\
\hline Business & 8.5 & 12.0 & 7.5 & 7.0 & 6.6 & 6.2 & 6.1 & 6.0 \\
\hline Dwelling & 5.2 & 3.1 & 0.2 & 0.7 & 1.8 & 2.3 & 2.4 & 2.4 \\
\hline Net exports $1 /$ & -0.6 & -1.7 & -1.6 & -0.2 & -0.5 & -0.3 & -0.1 & -0.2 \\
\hline $\mathrm{CPI}$ inflation & 2.6 & 2.3 & 4.4 & 3.5 & 3.0 & 2.8 & 2.8 & 2.8 \\
\hline Unemployment rate (percent) & 6.4 & 4.4 & 4.2 & 4.7 & 4.6 & 4.5 & 4.5 & 4.4 \\
\hline \multicolumn{9}{|l|}{ Saving and investment (percent of GDP) } \\
\hline Gross national saving & 20.3 & 22.2 & 21.5 & 22.5 & 22.7 & 22.5 & 22.2 & 21.9 \\
\hline General government saving & 3.8 & 4.1 & 4.6 & 4.4 & 4.3 & 4.1 & 4.0 & 3.9 \\
\hline Private saving $2 /$ & 16.5 & 18.1 & 16.9 & 18.1 & 18.4 & 18.4 & 18.3 & 17.9 \\
\hline Of which: Household & 5.9 & 6.6 & 6.3 & 7.8 & 7.7 & 7.8 & 7.9 & 7.9 \\
\hline Gross capital formation & 24.7 & 27.9 & 27.7 & 26.7 & 26.9 & 27.1 & 27.3 & 27.5 \\
\hline Of which: Private fixed investment & 20.8 & 23.1 & 22.9 & 22.4 & 22.7 & 22.9 & 23.1 & 23.3 \\
\hline \multicolumn{9}{|l|}{ Commonwealth budget (percent of GDP) $3 /$} \\
\hline Receipts (cash basis) & 25.6 & 26.0 & 26.2 & 25.4 & 25.7 & 25.7 & 25.5 & 25.5 \\
\hline Payments (cash basis) & 24.9 & 24.2 & 24.4 & 23.4 & 23.9 & 24.0 & 23.9 & 23.9 \\
\hline Underlying cash balance 4/ & 0.7 & 1.6 & 1.5 & 1.8 & 1.5 & 1.4 & 1.3 & 1.3 \\
\hline Fiscal balance (accrual basis) & 0.6 & 1.6 & 1.8 & 1.9 & 1.7 & 1.7 & 1.6 & 1.6 \\
\hline Net debt & 7.1 & -2.9 & -3.8 & -3.7 & -5.1 & -6.5 & -7.6 & -8.8 \\
\hline \multicolumn{9}{|l|}{ Balance of payments (percent of GDP) } \\
\hline Balance on goods and services & -1.3 & -1.7 & -1.5 & 1.5 & 0.8 & 0.4 & 0.0 & -0.4 \\
\hline Balance on income and transfers & -3.2 & -4.4 & -4.7 & -5.7 & -5.1 & -5.1 & -5.1 & -5.3 \\
\hline Current account balance & -4.5 & -6.1 & -6.1 & -4.2 & -4.3 & -4.6 & -5.1 & -5.6 \\
\hline \multicolumn{9}{|l|}{ Trade in goods and services (percent change) } \\
\hline Export volume & 3.8 & 3.2 & 4.6 & 8.5 & 6.2 & 5.7 & 5.7 & 5.8 \\
\hline Import volume & 8.2 & 10.6 & 10.5 & 7.6 & 6.9 & 5.6 & 5.1 & 5.3 \\
\hline Terms of trade & 3.9 & 4.3 & 7.2 & 13.8 & -2.4 & -1.9 & -2.3 & -2.2 \\
\hline Export price & 3.9 & 0.7 & 7.4 & 13.3 & -1.8 & -1.4 & -1.9 & -3.5 \\
\hline Import price & 0.1 & -3.5 & 0.2 & -0.5 & 0.7 & 0.5 & 0.4 & -1.4 \\
\hline \multicolumn{9}{|l|}{ External liabilities } \\
\hline Net external liabilities (percent of GDP) & 53.8 & 66.5 & 66.6 & 65.3 & 66.2 & 67.4 & 68.9 & 71.0 \\
\hline Net external interest (percent of exports) & 9.3 & 11.5 & 13.9 & 16.2 & 13.7 & 13.3 & 13.7 & 14.8 \\
\hline \multicolumn{9}{|l|}{ Memorandum Item: } \\
\hline Nominal GDP (in billions of Australian dollar) & 754 & 1,088 & 1,173 & 1,279 & 1,347 & 1,422 & 1,500 & 1,582 \\
\hline
\end{tabular}

Sources: Data provided by the Australian authorities; and staff estimates and projections.

$1 /$ Contribution to growth.

2/ Includes public trading enterprises.

3/ Fiscal year basis ending June 30. Projections through 2012 are as presented in the Budget Strategy and Outlook, 2008-09. For 2013, staff projections are used.

4/ Underlying cash balance equals receipts less payments, and excludes Future Fund earnings. 
Table 6. Australia: Indicators of External and Financial Vulnerability, 2004-08 (In percent of GDP, unless otherwise indicated)

\begin{tabular}{|c|c|c|c|c|c|}
\hline & 2004 & 2005 & 2006 & 2007 & $20081 /$ \\
\hline \multicolumn{6}{|l|}{ External indicators } \\
\hline Real exports of goods (percent change) & 3.9 & 2.3 & 3.1 & 2.5 & 2.5 \\
\hline Real imports of goods (percent change) & 14.4 & 9.9 & 8.3 & 10.5 & 10.6 \\
\hline Terms of trade (percent change) & 9.3 & 11.7 & 7.6 & 4.3 & 2.7 \\
\hline Current account balance & -6.0 & -5.8 & -5.5 & -6.1 & -6.4 \\
\hline Capital and financial account balance & 6.1 & 5.8 & 5.5 & 6.2 & 6.4 \\
\hline \multicolumn{6}{|l|}{ Of which: } \\
\hline Net portfolio investment & 2.6 & 5.3 & 6.9 & 0.5 & 1.3 \\
\hline Net direct investment & 3.9 & -0.2 & 0.4 & -0.2 & 0.6 \\
\hline Total reserves (in billions of U.S. dollar) & 36.9 & 43.3 & 55.1 & 26.9 & 33.4 \\
\hline In months of imports of goods and services & 3.2 & 3.6 & 3.8 & 1.5 & 1.6 \\
\hline Total net reserves (in billions of U.S. dollar) & 19.5 & 21.0 & 24.3 & 31.6 & 34.4 \\
\hline Net international investment position & -55.5 & -56.8 & -60.2 & -66.5 & -65.9 \\
\hline \multicolumn{6}{|l|}{ Of which: } \\
\hline Net external public sector debt & 1.6 & 1.0 & 0.2 & 3.6 & 2.8 \\
\hline Net external private sector debt & 45.9 & 49.0 & 51.8 & 52.2 & 52.9 \\
\hline Net interest payments to exports (in percent) & 9.1 & 8.8 & 10.3 & 11.5 & 11.3 \\
\hline Nominal effective exchange rate (percent change) & 7.5 & 2.5 & -1.2 & 6.8 & 7.1 \\
\hline \multicolumn{6}{|l|}{ Financial market indicators } \\
\hline General government gross debt (percent of GDP) & 11.3 & 10.4 & 9.3 & 8.2 & 8.0 \\
\hline \multicolumn{6}{|l|}{ Interest rates (percent, period average) } \\
\hline 3-month T-bill & 5.5 & 5.6 & 6.0 & 6.7 & 7.3 \\
\hline 3-month interest rate spread vis-à-vis US & 4.1 & 2.4 & 1.1 & 2.2 & 5.2 \\
\hline 10-year government bond & 5.6 & 5.3 & 5.6 & 6.0 & 5.9 \\
\hline Stock market index (ASX, percent change, end-year) & 22.6 & 16.2 & 19.9 & 13.8 & -9.5 \\
\hline \multicolumn{6}{|l|}{ Capital adequacy } \\
\hline Regulatory capital to risk-weighted assets & 10.5 & 10.4 & 10.4 & 10.2 & 10.5 \\
\hline Tier I capital to risk-weighted assets $2 /$ & 7.6 & 7.6 & 7.4 & 7.2 & 7.3 \\
\hline \multicolumn{6}{|l|}{ Asset quality } \\
\hline Impaired assets to total assets & 0.3 & 0.2 & 0.2 & 0.2 & 0.3 \\
\hline Specific provisions to impaired assets & 41.4 & 37.0 & 39.5 & 39.5 & 36.8 \\
\hline \multicolumn{6}{|l|}{ Loans composition (share of total) } \\
\hline Public sector & 2.2 & 1.5 & 1.4 & 1.3 & 1.0 \\
\hline Individuals & 62.1 & 62.3 & 60.4 & 54.6 & 54.2 \\
\hline Housing loans & 53.6 & 53.8 & 51.9 & 46.7 & 46.6 \\
\hline Investor housing & 18.4 & 18.2 & 17.2 & 15.4 & 15.3 \\
\hline Commercial lending & 35.7 & 36.3 & 38.2 & 44.1 & 44.7 \\
\hline Financial intermediaries & 7.8 & 7.5 & 8.8 & 12.8 & 12.7 \\
\hline Nonfinancial sector & 27.9 & 28.7 & 29.4 & 31.3 & 32.1 \\
\hline
\end{tabular}

Sources: Data from authorities and Fund staff estimates.

1/ Data are for latest available month.

2/ Tier I capital includes issued and fully paid common equity and perpetual noncumulative preference shares, and disclosed reserves. 
Table 7. Financial Sector Assessment Program:

Key Recommendations and Update on the Progress of Implementation ${ }^{1}$

Issue Key Recommendations Progress of Implementation

\begin{tabular}{|c|c|c|}
\hline Banking & $\begin{array}{l}\text { Continue to ensure strong risk } \\
\text { management practices, } \\
\text { including through regular } \\
\text { stress testing. }\end{array}$ & $\begin{array}{l}\text { The Basel II framework came into effect in January } 2008 \text {, with } \\
\text { regular stress testing forming an important element of the } \\
\text { framework. Three of the four largest banks were approved to adopt } \\
\text { the internal ratings based approach with respect to credit risk, and } \\
\text { supervisors have appropriately put safeguards in place to ensure } \\
\text { that the reduction in banks' capital is phased in. The fourth large } \\
\text { bank is expected to adopt the internal ratings based approach with } \\
\text { respect to credit risk by end-2008. }\end{array}$ \\
\hline
\end{tabular}

$\begin{array}{ll}\text { Failure } & \text { Continue to develop a formal } \\ \text { Resolution } & \text { process to manage the failure } \\ \text { and Crisis } & \text { of individual institutions and } \\ \text { Management } & \text { more widespread crises. }\end{array}$

In June 2008, the Government announced its intention to introduce to Parliament a Financial Claims Scheme (FCS) intended to provide depositors in a failed authorized deposit-taking institution (ADI) with timely access to the first $A \$ 20,000$ of their funds, and policyholders of a failed general insurer with a right to have claims met. The proposed legislation also includes broader crisis management arrangements, enhancing regulators' ability to deal with a distressed ADI or general insurer.

\begin{tabular}{ll}
\hline Supervisory & Ensure that the supervisory \\
Capacity & agencies have adequate \\
& resources and flexibility.
\end{tabular}

In the 2007/08 Budget, APRA received additional funding over a four-year period to improve its staff capabilities. The government has also enhanced APRA' flexibility by removing the requirement to obtain ministerial consent before taking administrative actions. The Australian Securities and Investments Commission (ASIC) also received substantial funding increases over recent years, in particular to fund a better regulation initiative program, to streamline the corporate register, and for the development of the ASIC's information technology systems over the next four years.

\begin{tabular}{|c|c|c|}
\hline \multirow[t]{2}{*}{$\begin{array}{l}\text { Cooperation } \\
\text { with New } \\
\text { Zealand } \\
\text { Regulators }\end{array}$} & \multirow{2}{*}{$\begin{array}{l}\text { Build on the progress made } \\
\text { within the Trans-Tasman } \\
\text { Council on Banking } \\
\text { Supervision to improve } \\
\text { coordination in crisis } \\
\text { management. }\end{array}$} & $\begin{array}{l}\text { Legislative changes formalizing a requirement on regulators in the } \\
\text { two countries to be alert to each other's interests in times of stress } \\
\text { came into force in both countries in December } 2006 \text {. }\end{array}$ \\
\hline & & $\begin{array}{l}\text { The work of the Trans-Tasman Council now focuses more on the } \\
\text { practical aspects of coordination in crisis management. }\end{array}$ \\
\hline Insurance & $\begin{array}{l}\text { Push ahead with Stage II } \\
\text { reforms (e.g., capital } \\
\text { management, reinsurance } \\
\text { documentation, corporate } \\
\text { governance standards, } \\
\text { disclosure requirements). }\end{array}$ & $\begin{array}{l}\text { Stage II reforms for nonlife insurance were completed in } 2006 \text {. } \\
\text { From July 1, 2008, all Direct Offshore Foreign Insurers operating in } \\
\text { Australia must be authorized by APRA and subject to Australia's } \\
\text { prudential regime. Discretionary Mutual Funds are now subject to } \\
\text { rigorous and compulsory information collection. APRA has a longer- } \\
\text { term aim to harmonize prudential requirements between life } \\
\text { insurance, general insurance, and banking sectors. }\end{array}$ \\
\hline \multirow[t]{2}{*}{ AML/CFT } & $\begin{array}{l}\text { Give high priority to make the } \\
\text { appropriate legislative and } \\
\text { operational arrangements in } \\
\text { the AML/CFT area. }\end{array}$ & $\begin{array}{l}\text { The AML/CFT Act was adopted in December } 2006 \text {. This first } \\
\text { tranche of reforms covers the activities of financial service } \\
\text { providers, gambling services and bullion dealers. Implementation is } \\
\text { proceeding in line with the adopted } 24 \text {-month schedule. }\end{array}$ \\
\hline & & $\begin{array}{l}\text { Work is underway on developing legislation for the second tranche } \\
\text { of legislative and regulatory reforms intended to capture designated } \\
\text { nonfinancial businesses and professionals. }\end{array}$ \\
\hline
\end{tabular}

Source: IMF Staff.

${ }^{1}$ A detailed discussion and a full list of recommendations can be found in the Financial System Stability Assessment (IMF Country Report No. 06/372). 
Figure 12. Australia: External Debt Sustainability: Bound Tests ${ }^{1 /}$

(Gross external debt in percent of GDP)
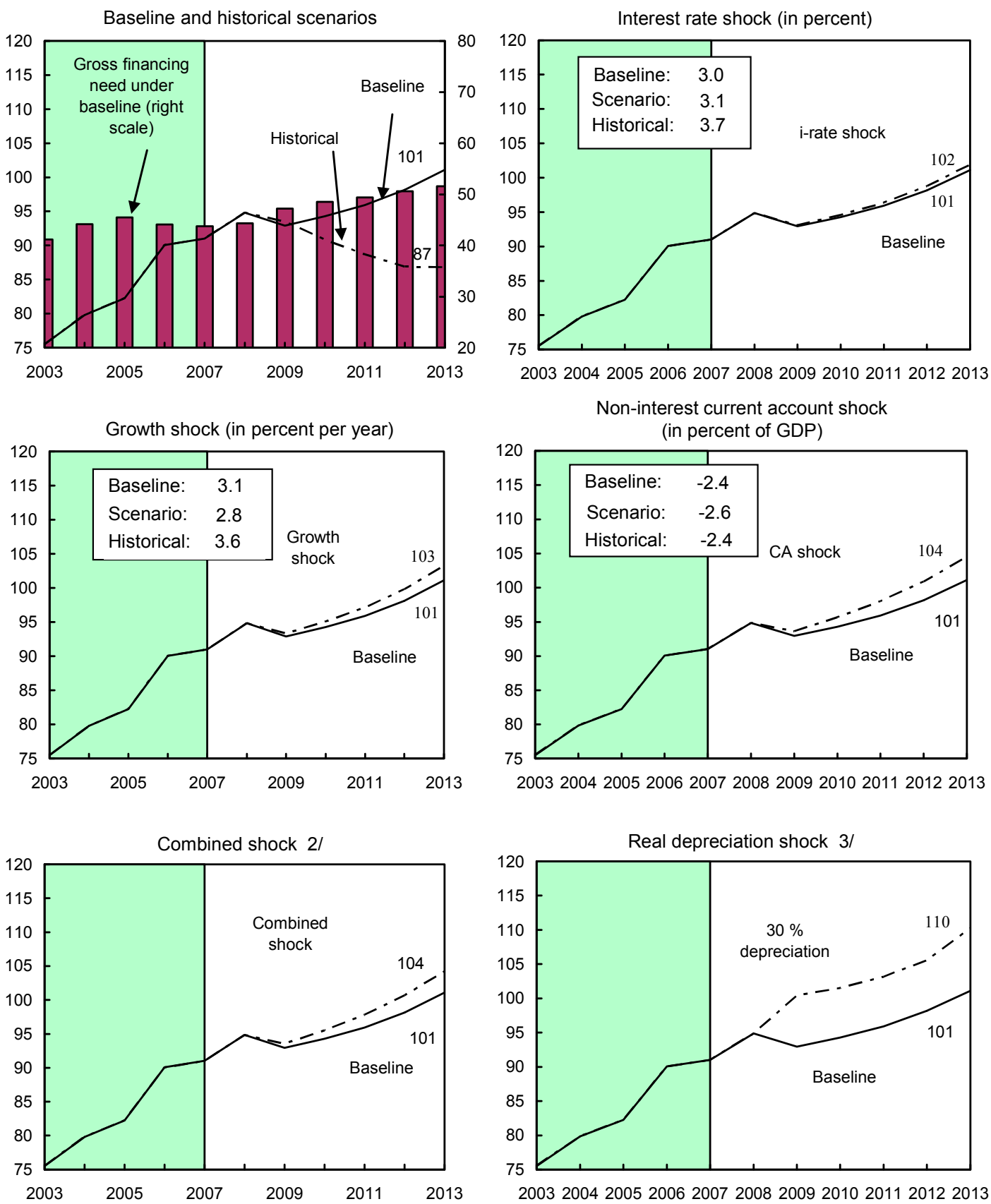

Sources: International Monetary Fund, Country desk data, and staff estimates.

1/ Shaded areas represent actual data. Individual shocks are permanent one-half standard deviation shocks. Figures in the boxes represent average projections for the respective variables in the baseline and scenario being presented. Ten-year historical average for the variable is also shown.

2/ Permanent 1/4 standard deviation shocks applied to real interest rate, growth rate, and current account balance. $3 /$ One-time real depreciation of 30 percent occurs in 2009. This scenario assumes foreign exchange hedging covers 79 percent of foreign currency debt, consistent with the findings of a survey by the Australian Bureau of Statistics, as reported in "Australia's Foreign Currency Exposure and Hedging Practices," RBA Bulletin, December 2005. 


\section{Appendix I. Exchange Rate Assessment Methodology and Confidence Intervals}

The desk estimates of the equilibrium value of the REER under the macroeconomic balance (MB) and the equilibrium real exchange rate (ERER) approaches are based on panel regression models estimated by the generalized method of moments (GMM). To control for endogeneity, lagged explanatory variables are employed as instruments, where appropriate. The tables and figures below summarize the results.

\begin{tabular}{|lcc|}
\hline \multicolumn{2}{|c|}{ MB Estimation Results for 55 Economies, 1973-07 } \\
\hline CA/GDP & Estimate & t Ratio \\
\hline Rel. old age dependency & -0.70 & -5.02 \\
Rel. population growth & -4.19 & -2.82 \\
Rel. income growth & -0.45 & -2.08 \\
Oil trade balance & 0.78 & 5.69 \\
Initial net foreign assets & 0.001 & 2.45 \\
\hline Observations & 838 \\
R Squared & 0.52 & \\
\hline
\end{tabular}

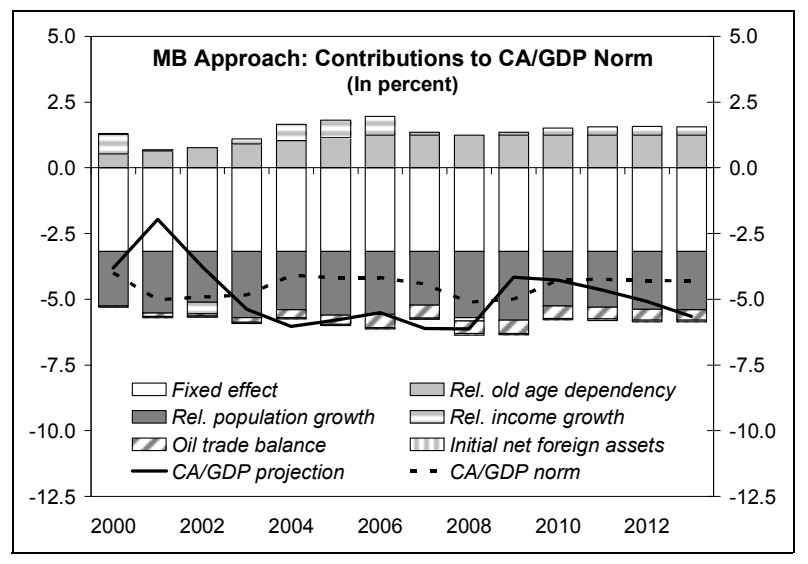

ERER Estimation Results for 55 Economies, 1973-07

\begin{tabular}{|lcc|}
\hline REER & Estimate & t Ratio \\
\hline Terms of trade & 0.36 & 3.78 \\
Rel. productivity & 0.24 & 5.33 \\
Rel. government consumption & 1.58 & 4.05 \\
\hline Observations & 945 & \\
R Squared & 0.51 & \\
\hline
\end{tabular}

The desk methodology allows confidence intervals to be calculated, as presented in the table. The wide confidence intervals suggest that the results of the exchange rate assessment need to be interpreted with caution. Further details are available in a forthcoming working paper.

\begin{tabular}{|c|c|c|c|}
\hline & \\
\hline
\end{tabular}




\title{
INTERNATIONAL MONETARY FUND
}

\author{
AUSTRALIA \\ Staff Report for the 2008 Article IV Consultation-Informational Annex \\ Prepared by the Staff Representatives for the 2008 Consultation with Australia \\ (In Consultation with Other Departments) \\ August 13, 2008 \\ Contents Page

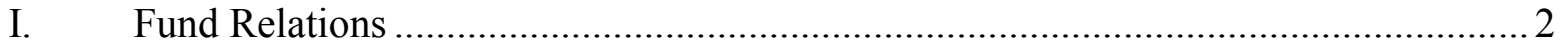

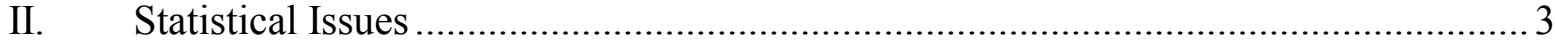


ANNEX I. AUSTRALIA-Fund RElations

(As of July 31, 2008)

I. Membership Status: Joined: August 5, 1947; Article VIII

II. General Resources Account:

Quota

Fund holdings of currency

Reserve position in Fund

III. SDR Department:

Net cumulative allocation

Holdings

IV. Outstanding Purchases and Loans:

V. Financial Arrangements:

VI. Projected Obligations to Fund:

\author{
SDR Million \\ $3,236.40$ \\ $2,997.38$ \\ 239.41
}
SDR Million
470.55
117.07

\author{
Percent Quota \\ 100.00 \\ 92.61 \\ 7.40
}

\section{Percent Allocation 100.00 \\ 24.88}

VII. Exchange Rate Arrangement. Australia has accepted the obligations of Article VIII, Sections 2, 3 and 4 of the Articles of Agreement, and maintains an exchange system that is free from restrictions on the making of payments and transfers for current international transactions, except for exchange restrictions that are maintained solely for the preservation of national or international security and which have been notified to the Fund pursuant to Executive Board Decision No. 144-(52/51). The exchange rate is independently floating, but the Reserve Bank of Australia retains discretionary power to intervene. There are no taxes or subsidies on purchases or sales of foreign exchange.

VIII. Restrictions on Capital Transactions. Australia maintains a capital transactions regime that is virtually free of restrictions. Two main restrictions on foreigners require: authorization for significant ownership of Australian corporations; and approval for acquisition of real estate.

IX. Article IV Consultation. Australia is on the 12-month consultation cycle. The 2007 Article IV consultation discussions were held during June 18-27, 2007, the Executive Board discussed the staff report (IMF Country Report No. 07/314) and concluded the consultation on August 31, 2007.

X. FSAP Participation. The FSAP missions took place during November 30December 14, 2005, and March 26-April 12, 2006. The FSSA (including financial sector ROSCs), the Detailed Assessment of Observance of Standards and Codes, and the Technical Note on Investor Protection, Disclosure, and Financial Literacy, were published as Country Reports No. 06/372, No. 06/415, and No. 06/437, respectively.

XI. Fourth Amendment. Australia has accepted the Fourth Amendment to the Articles of Agreement. 


\section{AnNeX II. Australia: Statistical Issues}

Data provision is adequate for surveillance. Australia subscribed to the Special Data Dissemination Standard (SDDS) and its metadata are posted on the Fund's Dissemination Standards Bulletin Board (DSBB). In recent years, the Australian Bureau of Statistics (ABS) has taken several initiatives to further improve the quality of the data, such as including the prices of financial services in the CPI and developing new measures of labor underutilization.

In September 2006, STA met with officials from the ABS, the Australian Prudential Regulation Authority, and the Reserve Bank of Australia to encourage the reporting of monetary data using the standardized report forms (SRFs) introduced in October 2004. The SRFs provide for accounting data to be broken down by instrument, sector, and currency.

Table of Common Indicators Required for Surveillance

(As of July 31, 2008)

\begin{tabular}{|c|c|c|c|c|c|}
\hline & $\begin{array}{c}\text { Date of } \\
\text { Latest } \\
\text { Observation }\end{array}$ & $\begin{array}{c}\text { Date } \\
\text { Received }\end{array}$ & $\begin{array}{c}\text { Frequency } \\
\text { of } \\
\text { Data }^{6}\end{array}$ & $\begin{array}{c}\text { Frequency } \\
\text { of } \\
\text { Reporting }^{6}\end{array}$ & $\begin{array}{c}\begin{array}{c}\text { Frequency } \\
\text { of } \\
\text { Publication }^{6}\end{array} \\
\end{array}$ \\
\hline Exchange Rates & $07 / 31 / 08$ & $07 / 31 / 08$ & $\mathrm{D}$ & $\mathrm{D}$ & $\mathrm{D}$ \\
\hline $\begin{array}{l}\text { International Reserve Assets and Reserve Liabilities } \\
\text { of the Monetary Authorities }{ }^{1}\end{array}$ & $06 / 08$ & 07/17/08 & M & M & M \\
\hline Reserve/Base Money & $05 / 08$ & 07/08/08 & M & M & M \\
\hline Broad Money & $05 / 08$ & 07/08/08 & M & M & M \\
\hline Central Bank Balance Sheet & $06 / 08$ & 07/17/08 & M & M & M \\
\hline Consolidated Balance Sheet of the Banking System & $05 / 08$ & 07/08/08 & M & M & M \\
\hline Interest Rates ${ }^{2}$ & $07 / 31 / 08$ & $07 / 31 / 08$ & $\mathrm{D}$ & $\mathrm{D}$ & $\mathrm{D}$ \\
\hline Consumer Price Index & Q2 2008 & 07/23/08 & Q & Q & Q \\
\hline $\begin{array}{l}\text { Revenue, Expenditure, Balance and Composition of } \\
\text { Financing }^{3} \text { - General Government }\end{array}$ & $2006 / 07$ & $10 / 07$ & A & A & A \\
\hline $\begin{array}{l}\text { Revenue, Expenditure, Balance and Composition of } \\
\text { Financing }{ }^{3} \text { - Central Government }\end{array}$ & $04 / 08$ & 07/17/08 & M & M & M \\
\hline $\begin{array}{l}\text { Stocks of Central Government and Central } \\
\text { Government-Guaranteed Debt }{ }^{5}\end{array}$ & $04 / 08$ & $07 / 17 / 08$ & M & M & M \\
\hline External Current Account Balance & Q1 2008 & $06 / 03 / 08$ & Q & Q & Q \\
\hline Exports and Imports of Goods and Services & $05 / 08$ & 07/17/08 & M & M & M \\
\hline GDP/GNP & Q1 2008 & $06 / 04 / 08$ & Q & Q & Q \\
\hline Gross External Debt & Q1 2008 & 06/03/08 & Q & Q & Q \\
\hline International Investment Position ${ }^{7}$ & Q1 2008 & $06 / 03 / 08$ & $\mathrm{Q}$ & $\mathrm{Q}$ & $\mathrm{Q}$ \\
\hline
\end{tabular}

${ }^{1}$ Includes reserve assets pledged or otherwise encumbered as well as net derivative positions.

${ }^{2}$ Both market-based and officially-determined, including discount rates, money market rates, rates on treasury bills, notes and bonds.

${ }^{3}$ Foreign, domestic bank, and domestic nonbank financing.

${ }^{4}$ Consists of the central government (including budgetary, extra budgetary, and social security funds) and state and local governments.

${ }^{5}$ Including currency and maturity composition.

${ }^{6}$ Daily (D), Weekly (W), Monthly (M), Quarterly (Q), Annually (A), Irregular (I); Not Available (NA).

${ }^{7}$ Includes external gross financial asset and liability positions vis a vis nonresidents. 
INTERNATIONAL MONETARY FUND

\author{
AUSTRALIA \\ Staff Report for the 2008 Article IV Consultation \\ Supplementary Information \\ Prepared by Asia and Pacific Department \\ Approved by Kalpana Kochhar and Tessa van der Willigen
}

September 5, 2008

1. This supplement to the staff report summarizes the main developments since the staff report was issued on August 11, 2008.

2. GDP growth moderated in the second quarter as expected. Real GDP grew by 1.2 percent in the June quarter in annualized seasonally adjusted terms, reducing growth to 2.7 percent in $y / y$ terms. Household consumption contracted slightly while private investment remained strong. The slowing in GDP growth was in line with staff projections, with growth in household consumption weaker than expected, but exports and private investment stronger than expected.

3. The staff's real GDP projections remain broadly unchanged, but the risks have become more balanced than characterized in the staff report. Household demand is likely to be weaker than projected in the staff report, with tight financial conditions offsetting the impact of personal tax cuts. Strong investment and exports, especially in the mining sector, are likely to continue to support growth.

4. Credit growth slowed sharply in recent months and the global financial turmoil continued to put upward pressure on banks' funding costs. Credit growth fell from 16 percent y/y in December 2007 to 6 percent in July 2008 (in seasonally adjusted, annualized terms), in response to higher interest rates and tightened credit standards. The financial turmoil continued to put upward pressure on banks' funding costs, with variable and fixed mortgages rates rising further in July. 

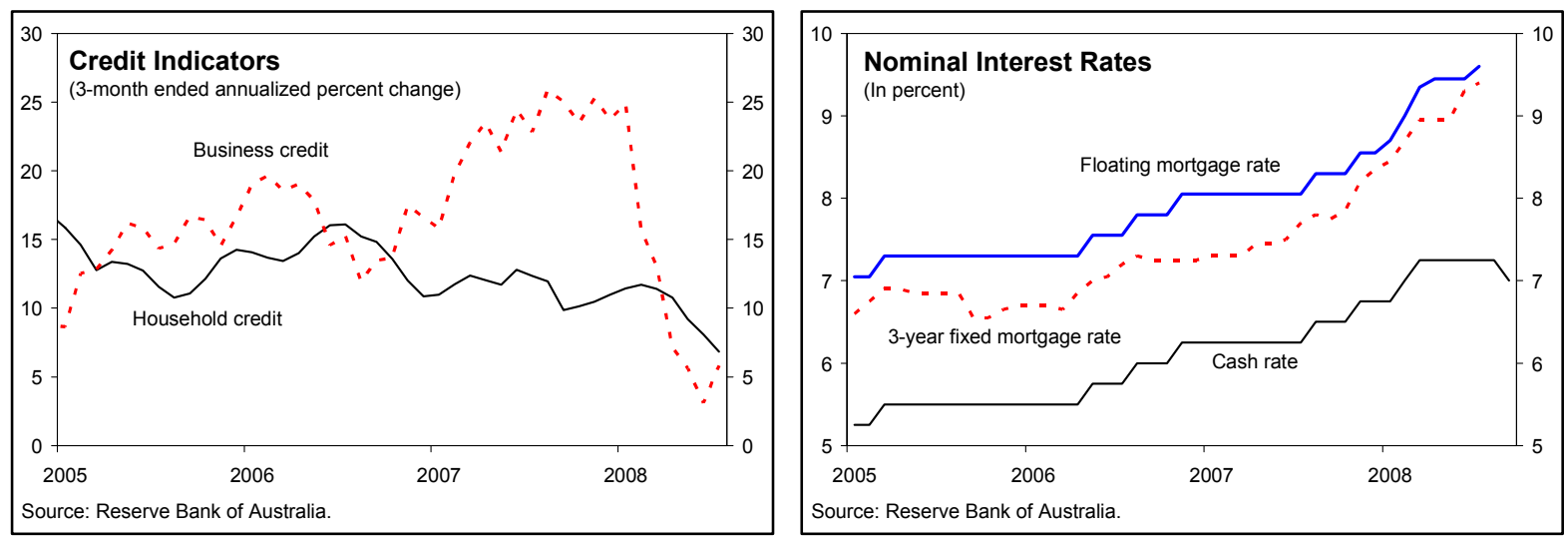

5. The Reserve Bank of Australia (RBA) moved to a less restrictive monetary policy stance on September 2, 2008 by reducing its cash rate by 25 basis points to 7 percent. The RBA noted that financial conditions had become quite tight in recent months, with heightened concerns over credit persisting in international financial markets. The RBA move offsets the tightening in financial conditions in recent months and the RBA continues to forecast inflation to fall below 3 percent in 2010.

6. In the staff's view, monetary policy remains sufficiently firm to reduce inflation but looking ahead it will be important to take a cautious approach. Even after factoring in the cut in the cash rate, bank lending rates are more than 150 basis points above mid-2007 levels and credit conditions more generally have tightened considerably. However, given high core inflation and pressures stemming from the commodity price boom and large immigration inflows, the RBA should take a cautious approach to policy adjustment.

7. The exchange rate has depreciated in the past month as interest rate differentials narrowed and some commodity prices eased. The Australian dollar has fallen by about 10 percent since June 2008, in nominal effective terms. The recent depreciation was driven by market expectations of an easing in monetary policy and a decline in base metal prices as global growth forecasts were revised downward. The staff report estimated an overvaluation of the Australian dollar of about 10 percent and the recent depreciation brings the currency into line with its medium-term equilibrium level.

8. The current account deficit narrowed to $4 \frac{1}{2}$ percent of GDP in the June quarter. The trade balance moved into surplus for the first time in six years, due to a sharp increase in export prices for iron ore and coal and a broader pickup in export volumes. The improvement in the trade balance was offset in part by a wider income deficit, as debt service costs and dividend payments increased. Net foreign liabilities were revised down by 4-5 percent of GDP for the past year, and stood at about 60 percent of GDP for June 2008. 


\section{INTERNATIONAL MONETARY FUND}

Public Information Notice (PIN) No. 08/123

FOR IMMEDIATE RELEASE

September 23, 2008
International Monetary Fund

$70019^{\text {th }}$ Street, NW

Washington, D. C. 20431 USA

\section{IMF Executive Board Concludes 2008 Article IV Consultation with Australia}

On September 10, 2008, the Executive Board of the International Monetary Fund (IMF) concluded the Article IV consultation with Australia. 1, 2

\section{Background}

Sound macroeconomic policies and structural reforms in Australia have delivered more than sixteen years of economic expansion. Recently a commodity price boom, driven by robust global demand, has pushed the economy up against capacity constraints. As resources pressures mounted, broad-based inflation pressures emerged, and CPI inflation rose to $4 \frac{1}{2}$ percent. The large current account deficit increased net foreign liabilities to 60 percent of GDP, accumulating primarily as debt on financial institutions' balance sheets.

In response to rising inflation, the Reserve Bank of Australia (RBA) tightened monetary policy, raising the cash rate 100 basis points between August 2007 and March 2008. In addition, higher funding costs from the global financial turmoil pushed up lending rates further and tightened credit conditions. Recently, the tight monetary conditions and deteriorating confidence slowed household expenditure, suggesting that the easing in growth required to return inflation to the target band has commenced. In early

\footnotetext{
${ }^{1}$ Under Article IV of the IMF's Articles of Agreement, the IMF holds bilateral discussions with members, usually every year. A staff team visits the country, collects economic and financial information, and discusses with officials the country's economic developments and policies. On return to headquarters, the staff prepares a report, which forms the basis for discussion by the Executive Board. At the conclusion of the discussion, the Managing Director, as Chairman of the Board, summarizes the views of Executive Directors, and this summary is transmitted to the country's authorities.

${ }^{2}$ Discussion was based on the staff report dated August 8, 2008 and the selected issues paper dated August 18, 2008, and updated by supplement 2 to the staff report dated September 5, 2008.
} 
September, the RBA reduced the cash rate by 25 basis points, assessing that markets had tightened monetary conditions beyond what was required to reduce inflation.

The Commonwealth government has run surpluses in recent years that have eliminated its net debt. Revenue outcomes have consistently surprised on the upside, driven in part by the buoyancy in corporate tax revenue related to the commodity boom. However, increased spending and tax cuts over the previous three years offset some of the restraint from the automatic stabilizers. In addition, the states increased capital spending, shifting their budget balances to small deficits. In the latest 2008-09 Budget (July-June), the new government has taken a more contractionary fiscal stance, with expenditure restraint and a higher projected underlying cash surplus.

The banking sector is sound with stable profits, high capitalization, and few nonperforming loans. The global financial turmoil has increased funding costs and highlighted the rollover risk associated with banks' short-term debt. Banks are adjusting the structure of their funding in response to the turmoil, increasing liquidity, and lengthening the maturity of their funding.

\section{Executive Board Assessment}

Executive Directors commended the Australian authorities on their impressive economic management in the fiscal, monetary, and structural areas, which has spurred a sustained and long-lasting economic expansion. Looking ahead, Directors considered that the sound macroeconomic framework should permit Australia to weather the global downturn and contain inflationary pressures.

Directors welcomed the authorities' confirmation of their strong commitment to the inflation targeting framework, which has served Australia well and will contribute to anchoring medium-term inflation expectations and facilitating a lasting reduction in price pressures. They noted that the RBA had responded to the buildup in inflationary pressures in recent years through a substantial tightening of monetary policy. More recently, against the backdrop of the global financial turmoil, the tightness of the financial markets, and the evolution of economic conditions, the RBA moved to a less restrictive monetary policy by reducing the cash rate. Directors welcomed this action and the authorities' readiness to follow a cautious monetary policy aimed at achieving the 23 percent inflation target range over time, based on a continuous assessment of prospects for demand and inflation in the period ahead. Wage and price developments in particular will require careful monitoring, taking into account the high core inflation and pressures stemming from the commodity price boom.

Directors welcomed the support that prudent fiscal policy is providing for monetary policy. They noted that the reduction in public spending growth in the latest budget will help reduce inflation, and the intention to save any further positive revenue outcomes in 2008/09 will allow the automatic stabilizers to work. Looking ahead, if growth and revenues are stronger than expected, Directors recommended that the surplus be allowed to exceed budget forecasts until it is clear that inflation will decline. They agreed that, to the extent that the improvement in the budget balance is structural and associated with permanently higher commodity prices, there should be scope to reduce taxes or increase spending over the medium term. Directors welcomed the 
establishment of three new funds for longer-term spending on health, education, and infrastructure, with contributions to come from the 2007/08 and 2008/09 surpluses.

Directors regarded the flexible exchange rate policy as appropriate, and observed that the currency appreciation in recent years had eased inflation pressures. Directors noted the staff's assessment that, with the recent depreciation, the Australian dollar is now broadly in line with medium-term fundamentals. They observed that wider current account deficits and the accumulation of external liabilities have increased external vulnerability in recent years. However, Directors considered that vulnerability will be contained as the associated high rates of investment contribute to export capacity, and as the medium-term external current account deficit narrows to its historical norm.

Directors considered that the banking system is sound, but that some vulnerabilities remain. They commended the authorities' timely and fitting response to the credit market turmoil, with the RBA providing liquidity support and the Australian Prudential Regulation Authority intensifying its monitoring of banks. Directors noted that the banking sector remains profitable and well capitalized. However, they encouraged the authorities to monitor carefully the sector's vulnerability to rollover risks arising from short-term wholesale funding and to the risks associated with the large indebtedness of the household sector. Directors commended the authorities for the progress in implementing the 2006 Financial Sector Assessment Program (FSAP) recommendations, including the strengthening of the failure resolution and crisis management framework. They also welcomed the planned introduction of liquidity guidelines to reduce the risk of disruptions arising from loss of access to offshore funding.

Directors encouraged the authorities to take advantage of the positive macroeconomic performance to advance structural reforms. They considered that, if implemented fully, the broad reform agenda should enhance the flexibility of the economy and lift productivity and labor force participation.

Public Information Notices (PINs) form part of the IMF's efforts to promote transparency of the IMF's views and analysis of economic developments and policies. With the consent of the country (or countries) concerned, PINs are issued after Executive Board discussions of Article IV consultations with member countries, of its surveillance of developments at the regional level, of post-program monitoring, and of ex post assessments of member countries with longer-term program engagements. PINs are also issued after Executive Board discussions of general policy matters, unless otherwise decided by the Executive Board in a particular case. The staff report (use the free Adobe Acrobat Reader to view this pdf file) for the 2008 Article IV Consultation with Australia is also available. 
Australia: Selected Economic Indicators, 2004-08

\begin{tabular}{|c|c|c|c|c|c|}
\hline & 2004 & 2005 & 2006 & 2007 & $\begin{array}{l}2008 \\
\text { Proj. }\end{array}$ \\
\hline \multicolumn{6}{|l|}{ Output and demand (percent change) } \\
\hline Real GDP & 3.9 & 2.9 & 2.7 & 4.3 & 2.7 \\
\hline Total domestic demand & 5.9 & 4.4 & 3.1 & 5.9 & 4.1 \\
\hline Private consumption & 5.9 & 3.0 & 3.1 & 4.6 & 3.9 \\
\hline Total investment & 8.0 & 8.0 & 5.2 & 8.5 & 6.2 \\
\hline Business & 13.0 & 15.2 & 8.0 & 12.0 & 7.5 \\
\hline Dwelling & 3.0 & -3.5 & -2.4 & 3.1 & 0.2 \\
\hline Net exports $1 /$ & -1.9 & -1.3 & -0.9 & -1.7 & -1.6 \\
\hline \multicolumn{6}{|l|}{ Inflation and unemployment (in percent) } \\
\hline CPI inflation & 2.3 & 2.7 & 3.5 & 2.3 & 4.4 \\
\hline Unemployment rate & 5.4 & 5.1 & 4.8 & 4.4 & 4.2 \\
\hline \multicolumn{6}{|l|}{ Saving and investment (in percent of GDP) } \\
\hline Gross national saving & 20.2 & 20.9 & 21.6 & 22.2 & 21.5 \\
\hline General government saving & 3.6 & 4.3 & 5.0 & 4.1 & 4.6 \\
\hline Private saving $2 /$ & 16.6 & 16.6 & 16.6 & 18.1 & 16.9 \\
\hline Gross capital formation & 26.1 & 27.0 & 26.6 & 27.9 & 27.7 \\
\hline \multicolumn{6}{|l|}{ Fiscal indicators cash basis (in percent of GDP) 3/ } \\
\hline Receipts & 25.9 & 26.3 & 26.5 & 26.0 & 26.2 \\
\hline Payments & 24.9 & 24.8 & 24.8 & 24.2 & 24.4 \\
\hline Underlying balance & 1.0 & 1.5 & 1.6 & 1.6 & 1.5 \\
\hline Net debt & 2.8 & 1.4 & -0.6 & -2.9 & -3.8 \\
\hline \multicolumn{6}{|l|}{ Money and credit (end of period) } \\
\hline Interest rate (90-day bill, in percent) 4/ & 5.4 & 5.6 & 6.4 & 6.8 & 7.3 \\
\hline Treasury bond yield (10-year, in percent) $4 /$ & 5.3 & 5.2 & 5.9 & 5.9 & 5.7 \\
\hline M3 (percent change) $5 /$ & 8.9 & 8.2 & 13.0 & 22.5 & 17.6 \\
\hline Private domestic credit (percent change) 5/ & 14.1 & 13.5 & 14.2 & 15.3 & 12.8 \\
\hline \multicolumn{6}{|l|}{ Balance of payments (in percent of GDP) } \\
\hline Current account & -6.0 & -5.8 & -5.5 & -6.1 & -6.1 \\
\hline Of which: Trade balance & -2.8 & -1.9 & -1.3 & -1.9 & -1.6 \\
\hline Foreign direct investment (net) & 3.9 & -0.2 & 0.4 & -0.2 & 0.7 \\
\hline Terms of trade (percent change) & 9.3 & 11.7 & 7.6 & 4.3 & 7.2 \\
\hline \multicolumn{6}{|l|}{ External assets and liabilities (in percent of GDP) } \\
\hline Net external liabilities & 55.5 & 56.8 & 60.2 & 66.5 & 66.6 \\
\hline Net external debt & 47.5 & 50.0 & 52.0 & 55.8 & 56.3 \\
\hline Gross official reserves $6 /$ & 5.5 & 6.3 & 6.9 & 7.4 & 3.1 \\
\hline \multicolumn{6}{|l|}{ Exchange rate (period average) } \\
\hline U.S. dollar/Australian dollar 4/ & 0.74 & 0.76 & 0.75 & 0.84 & 0.93 \\
\hline Trade-weighted index 4/ & 62.3 & 63.9 & 63.0 & 67.5 & 70.7 \\
\hline Real effective exchange rate $7 /$ & 121.2 & 124.8 & 124.7 & 133.3 & 139.4 \\
\hline \multicolumn{6}{|c|}{$\begin{array}{l}\text { Sources: Data provided by the Australian authorities; and IMF staff estimates and projections, as } \\
\text { presented in the staff report dated August } 11,2008 . \\
1 \text { / Contribution to growth. } \\
2 \text { / Includes public trading enterprises. } \\
\text { 3/ Fiscal year ending June } 30 \text {, Commonwealth Budget. } \\
\text { 4/ Data for } 2008 \text { are for latest available month (August). } \\
\text { 5/ Data for } 2008 \text { are for latest available month (June). } \\
6 \text { / Data for } 2008 \text { are for latest available month (July). }\end{array}$} \\
\hline
\end{tabular}




\section{Statement by Richard Murray, Executive Director for Australia September 10, 2008}

As outlined in the supplement to the staff report released today, economic conditions have evolved since Australia's 2008 Article IV discussions were concluded at the end of July, with the latest information confirming that economic activity has slowed. This has led to a change in the authorities' assessment of the economic outlook and balance of risks, with implications for monetary policy.

\section{Economic Activity and Inflation}

The Australian economy is in its eighteenth year of expansion, underpinned by a strong macroeconomic policy framework and a boost to productive capacity from microeconomic reforms. In addition, strong growth in global commodity prices has pushed Australia's terms of trade to the highest level in over 50 years, boosting growth, profits and government revenues. In the early part of this year, domestic spending remained strong and most measures of capacity utilization were at levels consistent with previous cyclical peaks. Available labour has become more scarce, with labour force participation rising to record highs and the unemployment rate falling to levels last seen in Australia in the 1970s. It is against this background, and in combination with rising global fuel and food prices, that headline inflation rose to 4.5 per cent in the year to the June quarter 2008. Price pressures have become broadly based, with measures of underlying inflation rising to around 4 per cent. To date, however, wages growth has remained fairly stable, with annual growth around 4 per cent for the past three years.

Assessments of the economic outlook are complicated by the countervailing forces confronting the Australian economy. Slower global growth, tighter financial conditions and high petrol prices are exerting downward pressure on economic activity. On the other hand, the rise in the terms of trade is continuing to boost national income and business investment. On balance, the authorities' assessment at the time of the Article IV discussions in June was that these forces were likely to result in a slowing in GDP growth even as income growth remained high.

In the event, the latest information confirms that a significant moderation in spending and activity is now underway. The June quarter national accounts (released on 3 September) show that real GDP growth slowed to 2.7 per cent over the year to the June quarter, with the quarterly growth rate of 0.3 per cent the lowest in around four years. The slowdown is most apparent in the household sector, with household consumption falling slightly in the June quarter and consumer sentiment falling to 15 -year lows. The housing sector has also 
softened, with national house prices flat in the first half of the year and forward indicators pointing to declines in housing construction activity in the near-term. Business investment, particularly in the mining sector, continues to drive growth, although economy-wide indicators of business conditions have moderated, measures of capacity utilization are falling and there are early signs that demand for labour has started to ease.

Demand pressures are expected to ease further over the period ahead, with the likelihood that growth will remain significantly below the trend rate in both 2008-09 and 2009-10. Employment growth is also expected to moderate as economic growth slows and the unemployment rate, while remaining low, is expected to rise to 43/4 per cent by mid 2009 . The Reserve Bank of Australia's (RBA) forecasts in its August Statement on Monetary Policy were for underlying inflation to remain around 4 to $4 \frac{1}{2}$ per cent over the year to the December quarter and then to decline gradually to $23 / 4$ per cent by the end of $2010-$ consistent with the monetary policy target of 2 to 3 per cent inflation, on average, over the economic cycle.

\section{Monetary Policy}

In recent years, the RBA has responded to building inflationary pressures through a substantial tightening of monetary policy. The official cash rate was increased by a cumulative 300 basis points from mid-2002 to March 2008, including a rise of 100 basis points from August 2007. In the wake of the global financial turmoil, credit conditions have also tightened due to banks passing on increased funding costs to borrowers (adding a further 50-80 basis points to average bank lending rates since August 2007), higher risk spreads in corporate bond markets, falling equity prices and tougher lending standards for some types of borrowing. Combined with some fall in demand, this has resulted in a significant decline in credit growth, which slowed from an average monthly rate of 1.3 per cent over the December quarter 2007 to an average monthly rate of 0.5 per cent over the June quarter, consistent with other indicators of softer domestic activity.

In this context, the RBA Board decided to lower the cash rate by 25 basis points at its September meeting to 7.0 per cent. The RBA Governor noted in his press statement announcing the decision that tight financial conditions, in conjunction with other factors including higher fuel costs and lower asset values, have exerted the needed restraint on demand. Weighing up the latest information on economic activity and financial conditions, both in Australia and internationally, the RBA Board judged that there was now scope for monetary policy to become less restrictive.

Going forward, monetary conditions remain tight and the RBA Board will continue to assess prospects for demand and inflation over the period ahead, setting monetary policy as needed to bring inflation back to the 2-3 per cent target range over time. 


\section{Fiscal Policy}

The new Australian Government's medium-term fiscal strategy involves: achieving budget surpluses, on average, over the medium-term; keeping taxation as a share of GDP on average below the level for 2007-08, thereby ensuring that budget surpluses are achieved through disciplined spending, not higher taxation; and improving the Government's net financial worth over the medium-term in order to promote medium-term fiscal sustainability and policies that contribute to Australia's long-term productive capacity.

Against this strategy, the Federal Government introduced a contractionary 2008-09 Budget directed at easing domestic inflationary pressures, with an underlying 2008-09 cash surplus equivalent to 1.8 per cent of GDP. Further budget surpluses in the order of $1 \frac{1}{2}$ per cent of GDP are projected over the following three fiscal years, which would see the Government's net financial worth increase significantly. The combined budget deficit of the State and Territory Governments rose to around $1 / 2$ a per cent of GDP in 2007-08 due to increased infrastructure spending, but is forecast to remain broadly stable in 2008-09 - implying no additional fiscal stimulus.

The increase in the central Government's cash surplus in 2008-09 will be achieved while reducing tax as a share of GDP (from 24.7 per cent in 2007-08 to 23.8 per cent in 2008-09) through restraint on the expenditure side, with growth in real spending reduced to 1.1 per cent - the lowest rate in nine years. The Government has stated that further steps will be taken as necessary to place further downward pressure on inflation. As noted in the staff report, the Government is committed to maintaining tight controls on expenditure - including through ongoing efforts to reduce spending and direct it to areas that are more productive and saving any positive revenue surprises in 2008-09.

In addition to reducing short-term inflationary pressures, the 2008-09 Budget also contained measures to build the supply-side capacity of the economy over the medium- to long-term. This includes personal income tax cuts to promote increased workforce participation and the establishment of three new funds - which will amount to around 4 per cent of GDP designed to raise productivity growth through greater investment in infrastructure, education and health. The Government will make initial contributions to these funds from the 2007-08 and 2008-09 Budget surpluses, once realised. The Government has also committed to making further contributions from future surpluses as appropriate and ensuring that medium-term spending from the funds does not prejudice the monetary policy inflation target.

\section{Exchange Rate and External Stability}

Australia's flexible exchange rate has again proven to be an effective counter-cyclical force during the current commodity price boom. Widening interest rate differentials and the rapid 
increase in Australia's terms of trade have led to substantial appreciation of Australia's real trade-weighted exchange rate, contributing to the overall tightening of monetary conditions.

A number of factors support the analysis in the staff report that any overvaluation of Australia's real effective exchange rate would likely be temporary, with expectations of declining inflation, some narrowing of interest rate differentials and any further moderation in global commodity prices all supporting a reduction over the medium-term. Indeed, since the conclusion of the Article IV mission at the start of July, Australia's trade-weighted exchange rate has fallen by around 10 per cent in nominal terms, reflecting broader trends in global commodity prices and currency markets and a changed assessment of the near-term domestic interest rate outlook (detailed above).

Australia's current account deficit fell sharply to 4.4 per cent of GDP in the June quarter. High prices for export commodities have led to a sharp turnaround in the trade balance from a sizeable deficit in the March quarter to a small surplus in the June quarter. However, the net income deficit has remained high, reflecting robust growth in corporate profits, particularly in the mining sector ${ }^{1}[1]$, and rising net interest payments from a higher stock of net foreign debt. The outlook is for Australia's current account deficit to remain around historical norms of 4 to 5 per cent of GDP as domestic demand moderates, rural exports rebound and as significant investment projects in the mining sector continue to come on stream.

Australia's net external liabilities have risen in recent years, however there are a number of factors mitigating Australia's external vulnerability, including the minimal currency risk associated with the foreign debt and the soundness of the banking system through which the vast majority of Australia's foreign debt is channeled. Moreover, from a sectoral net lending perspective, the increase in Australia's net borrowing position can be attributed to exceptionally high rates of investment by the non-financial corporate sector. As a share of GDP, gross investment by the non-financial corporate sector has increased by nearly 4 percentage points over the last five years, causing the net borrowing position of the nonfinancial corporate sector to increase despite strong growth in profits. Over time, this investment is expected to raise the economy's productive capacity and stabilize net external liabilities, supporting the authorities' view - shared by Fund staff ${ }^{2}$ - that Australia's external position is sustainable over the medium-term.

\footnotetext{
${ }^{1}$ Balance of payments accounting records profits by foreign-owned corporations that are retained for investment in Australia as a dividend outflow on the current account and an investment inflow on the capital account.

2 “Australia's Large and Sustained Current Account Deficits: Should Consenting Adults be Trusted?” IMF Country Report No: 06/373 (10/23/06).
} 


\section{Financial Sector}

Australia's financial system has coped better with the ongoing turmoil than those of many other advanced countries. The banks have continued to record high levels of profits, have low levels of problem loans, and are soundly capitalized. They have maintained their high credit ratings through the recent turmoil and it is notable that of the world's largest 100 banks, only a handful have higher ratings than those of the four large Australian banks.

The solid position of the Australian banking system partly reflects the high quality of its assets. While non-performing loan ratios have picked up over the past few years, they remain low by historical and international standards. Competitive pressures saw lending criteria relaxed over recent years, but credit standards in Australia did not fall to the same degree as they did in the United States. A strong legal and regulatory framework is one factor that helped keep a check on this process. The Australian banks also have minimal direct exposure to the sub-prime problems, and they typically earn less of their revenues from trading in financial markets than many overseas banks.

Despite this relatively favourable position, the Australian banking sector has not been immune from developments abroad. As elsewhere, bank share prices have fallen considerably and funding costs have risen significantly. As noted above, the higher funding costs have been passed through to borrowers, with banks raising their lending rates by more than the increase in the cash rate over the past year.

The banks have also been taking a more cautious approach to their lending recently and have significantly increased their holdings of liquid assets. Importantly, the large banks have maintained their access to both the domestic and international capital markets, albeit at a higher cost than previously, to help finance the strong growth in their assets. Earlier in the year, in particular, the banks issued a record volume of bonds in offshore markets, and they are now well ahead in their funding plans. Banks have also benefited recently from considerably stronger growth in their deposits given the volatility in alternative investment markets.

Notwithstanding the resilience of the Australian financial system, the authorities are actively addressing the recommendations of the Financial Stability Forum (FSF) set out in its recent report on Enhancing Market and Institutional Resilience. As a member of the FSF, the Governor of the RBA has encouraged the large Australian banks to provide disclosures consistent with the best-practice template recommended by the FSF. The Basel II capital framework was implemented in Australia at the beginning of this year, and the Australian Prudential Regulation Authority (APRA) is continuing to review its operation with a view to strengthening requirements where necessary. In addition, APRA is undertaking a thorough review of its liquidity prudential standards, with a focus on improved disclosure and stress testing. The authorities are also conducting a review of the regulation of credit rating 
agencies in Australia. The RBA's open market operations are already sufficiently flexible, including in relation to the range of collateral it will accept, such that it sees no need to change them in light of the FSF's recommendations.

In line with FSF and earlier FSAP recommendations, the authorities are continuing to strengthen the framework for crisis management and resolution, including the establishment of a Financial Claims Scheme, under which depositors in a closed deposit-taking institution, or general insurance policyholders in a closed general insurer, would receive at least some of their funds on a timely basis. This approach will strengthen the existing provisions of the Banking Act which give depositors first claim over the assets of a failed authorised deposittaking institution. Legislative changes will also be made to enhance the regulators' powers to manage a troubled financial institution. The authorities are also continuing to engage with the New Zealand authorities on trans-Tasman crisis management issues, including how they would deal with stress at the parent and/or subsidiary of a bank with a significant transTasman presence.

\section{Structural Reform Agenda}

Since coming to office in late 2007, the Government has embarked on an ambitious structural reform agenda, summarized in broad terms on page 22 of the staff report. In addition to the three new funds announced in the Budget (detailed above), two areas of particular relevance are: the Government's commitment to introducing an emissions trading scheme from 2010; and a comprehensive review of the tax and transfer system that is currently underway.

\section{Conclusion}

Finally, our Australian authorities would like to thank Ray Brooks and his team for the constructive policy discussions during the Article IV mission, reflected in their high quality staff report and selected issues paper. 